\title{
Alpha and beta diversity patterns of polychaete assemblages across the nodule province of the eastern Clarion-Clipperton Fracture Zone (equatorial Pacific)
}

\author{
Paulo Bonifácio $^{1}$, Pedro Martínez Arbizu ${ }^{2}$, and Lénaïck Menot ${ }^{1}$ \\ ${ }^{1}$ Ifremer, Centre Bretagne, REM EEP, Laboratoire Environnement Profond, ZI de la Pointe du Diable, \\ CS 10070, 29280 Plouzané, France \\ ${ }^{2}$ German Centre for Marine Biodiversity Research (DZMB), Senckenberg am Meer, 26382 Wilhelmshaven, Germany
}

Correspondence: Lénaïck Menot (lenaick.menot@ifremer.fr) and Paulo Bonifácio (bonif@me.com)

Received: 28 June 2019 - Discussion started: 4 July 2019

Revised: 16 January 2020 - Accepted: 21 January 2020 - Published: 20 February 2020

\begin{abstract}
In the abyssal equatorial Pacific Ocean, most of the seafloor of the Clarion-Clipperton Fracture Zone (CCFZ), a 6 million $\mathrm{km}^{2}$ polymetallic nodule province, has been preempted for future mining. In light of the large environmental footprint that mining would leave and given the diversity and the vulnerability of the abyssal fauna, the International Seabed Authority has implemented a regional management plan that includes the creation of nine Areas of Particular Environmental Interest (APEIs) located at the periphery of the CCFZ. The scientific principles for the design of the APEIs were based on the best - albeit very limited - knowledge of the area. The fauna and habitats in the APEIs are unknown, as are species' ranges and the extent of biodiversity across the CCFZ.
\end{abstract}

As part of the Joint Programming Initiative Healthy and Productive Seas and Oceans (JPI Oceans) pilot action "Ecological aspects of deep-sea mining", the SO239 cruise provided data to improve species inventories, determine species ranges, identify the drivers of beta diversity patterns and assess the representativeness of an APEI. Four exploration contract areas and an APEI (APEI no. 3) were sampled along a gradient of sea surface primary productivity that spanned a distance of $1440 \mathrm{~km}$ in the eastern CCFZ. Between three and eight quantitative box cores $\left(0.25 \mathrm{~m}^{2} ; 0-10 \mathrm{~cm}\right)$ were sampled in each study area, resulting in a large collection of polychaetes that were morphologically and molecularly (cytochrome c oxidase subunit I and $16 \mathrm{~S}$ genes) analyzed.

A total of 275 polychaete morphospecies were identified. Only one morphospecies was shared among all five study ar- eas and $49 \%$ were singletons. The patterns in community structure and composition were mainly attributed to variations in organic carbon fluxes to the seafloor at the regional scale and nodule density at the local scale, thus supporting the main assumptions underlying the design of the APEIs. However, the APEI no. 3, which is located in an oligotrophic province and separated from the CCFZ by the Clarion Fracture Zone, showed the lowest densities, lowest diversity, and a very low and distant independent similarity in community composition compared to the contract areas, thus questioning the representativeness and the appropriateness of APEI no. 3 to meet its purpose of diversity preservation. Among the four exploration contracts, which belong to a mesotrophic province, the distance decay of similarity provided a species turnover of 0.04 species $\mathrm{km}^{-1}$, an average species range of $25 \mathrm{~km}$ and an extrapolated richness of up to 240000 polychaete species in the CCFZ. By contrast, nonparametric estimators of diversity predict a regional richness of up to 498 species. Both estimates are biased by the high frequency of singletons in the dataset, which likely result from undersampling and merely reflect our level of uncertainty. The assessment of potential risks and scales of biodiversity loss due to nodule mining thus requires an appropriate inventory of species richness in the CCFZ. 


\section{Introduction}

The abyssal depths are vast, covering $54 \%$ of the Earth's surface and $75 \%$ of the ocean floor, typically located between 3000 and $6000 \mathrm{~m}$ depth; it generally features lowtemperature, low-current and well-oxygenated oligotrophic waters (Gage and Tyler, 1991; Smith and Demopoulos, 2003; Ramirez-Llodra et al., 2010). Only about $1 \%$ of abyssal depths have been investigated to date: much remains to be discovered. Polymetallic nodule fields are one of the unique habitats in the abyss (Ramirez-Llodra et al., 2010; Vanreusel et al., 2016). Nodules are potato-shaped, variably sized aggregations of minerals, mainly manganese and iron but also copper, nickel, and cobalt, that are patchily distributed (Hein and Petersen, 2013; Morgan, 2000). Polymetallic nodules were discovered during the Challenger expedition in the 1870s at depths below $4000 \mathrm{~m}$ in the Pacific, Atlantic and Indian oceans (Murray and Renard, 1891). In the equatorial Pacific Ocean, the Clarion-Clipperton Fracture Zone (CCFZ) harbors the largest polymetallic nodule field, with nodule densities as high as $75 \mathrm{~kg} \mathrm{~m}^{-2}$ (average $15 \mathrm{~kg} \mathrm{~m}^{-2}$ ) and possibly containing 34 billion metric tons of manganese nodules (Hein and Petersen, 2013; Morgan, 2000), which may represent a minimum sale value of USD 25 trillion (Volkmann et al., 2018). The presence of abundant metal resources has attracted the interest of industries. Established by the United Nations Convention on the Law of the Sea (UNCLOS), the International Seabed Authority (ISA) manages the deep-sea mineral resources in international waters and is in charge of protecting fauna against any harm (Articles 145, 156, UNCLOS, 1982; Lodge et al., 2014). Currently, the ISA has granted 16 nodule exploration contracts and approved nine Areas of Particular Environmental Interest (APEIs) for preservation (Lodge et al., 2014) in the CCFZ.

Among the current seabed mining technologies, the hydraulic collector seems the most effective for commercial utilization (Jones et al., 2017). The mining pre-prototype vehicle $(4.7 \times 12 \mathrm{~m})$ presented by GSR is a pickup system based on four nodule collector heads $(1 \mathrm{~m}$ wide each) using a jet water pump and suction to collect nodules down to $15 \mathrm{~cm}$ depth (Global Sea Mineral Resources NV, 2018). A mining operation is anticipated to directly affect over $100 \mathrm{~km}^{2} \mathrm{yr}^{-1}$ of the seabed (Volkmann and Lehnen, 2018) and create sediment plumes that can indirectly increase the footprint of mining by a factor of 2 to 5 (Oebius et al., 2001; Glover and Smith, 2003). Nodule mining will clearly have detrimental effects on the benthic ecosystem, but the severity of the impacts is difficult to predict. Long-term surveys of small-scale disturbances or mining tests have shown that the direct impacts of seafloor disturbances may last for over 30 years in the CCFZ (Vanreusel et al., 2016; Jones et al., 2017). However, such small experiments hardly mimic the cumulative impacts of any single nodule mining operation that could last for 20 years (Glover and Smith, 2003; Jones et al., 2017). Beyond the unpredictable effects of the full-scale mining, the extent of biodiversity and species' ranges in the CCFZ are two major unknowns that prevent the assessment of potential biodiversity loss due to nodule mining. The few biodiversity studies undertaken so far in the CCFZ have revealed a high diversity of communities of megafauna (over 130 morphospecies; Amon et al., 2016; Simon-Lledó et al., 2019), polychaetes (over 180 morphospecies; Paterson et al., 1998; Glover et al., 2002; Wilson, 2017), isopods (over 160 morphospecies; Wilson, 2017), tanaids (over 100 morphospecies; Wilson, 2017; Błażewicz, et al., 2019) and nematodes (over 300 morphospecies; Miljutina et al., 2010). Overall, over 870 morphospecies are already known in the CCFZ, but almost none have been named and $90 \%$ are likely new to science (Glover et al., 2002; Miljutina et al., 2010). Therefore, new inventories of CCFZ biodiversity cannot be compared with these previous ones. To overcome this bias, DNA taxonomy is increasingly used (Glover et al., 2016). In the CCFZ, in two exploration contract areas separated by $1300 \mathrm{~km}$, the first assessment of macrofaunal diversity based on DNA taxonomy already increased the number of known polychaetes to 233 Molecular Operational Taxonomic Units (MOTUs; Janssen et al., 2015). This study further highlighted three characteristics of abyssal biodiversity: (i) high rates of species turnover (i.e., species replacement), with only $12 \%$ of polychaete MOTUs and $1 \%$ of isopod MOTUs shared between the two areas; (ii) high frequencies of singletons (MOTUs known from a single unique DNA sequence) ranging from $60 \%$ to $70 \%$ for polychaetes and isopods, respectively; and (iii) cryptic diversity within polychaete and isopod morphospecies, suggesting that previous surveys have underestimated alpha and beta diversity of these two taxa.

Considering the large environmental footprint of nodule mining disturbances on the seafloor, as well as the diversity and vulnerability of the abyssal fauna, the need for marine spatial planning to preserve species, habitats and functions in the CCFZ has emerged, concomitant to a renewed interest for deep-sea mineral resources (Wedding et al., 2013). Due to the paucity of biological data in the CCFZ, the recommendations issued by Wedding et al. (2013) for the design of a network of protected areas were mainly based on nitrogen flux at $100 \mathrm{~m}$ depth (a proxy for trophic inputs to the seafloor), modeled nodule densities, the distribution of large seamounts and the dispersal distances of shallow water taxa. One of the main assumptions underlying the management plan is that longitudinal and latitudinal productivity-driven gradients shape the community structure and species distribution of abyssal communities. As a result, Wedding et al. (2013) divided the spatial domain of the CCFZ into $3 \times 3$ subregions and suggested creating one large no-mining area in each subregion. The size of the no-mining areas was defined with the aim of maintaining viable population sizes for species potentially restricted to a subregion, taking into account the inferred dispersal distances of species and of the plumes created by nodule mining (Wedding et al., 2013). Those principles were implemented in the regional management plan for the CCFZ, which re- 
sulted in the designation of nine APEIs (Lodge et al., 2014). However, most of the CCFZ had already been preempted by current exploration contracts and areas reserved for future exploration. Consequently, the APEIs were located at the periphery of the CCFZ, thus deviating from an optimal design.

The European project Managing Impacts of Deep-seA reSource exploitation (MIDAS) and the Joint Programming Initiative Healthy and Productive Seas and Oceans (JPI Oceans) pilot action "Ecological aspects of deep-sea mining" was aimed at improving the scientific basis on which to assess and manage the potential impacts arising from nodule mining. In this context, four exploration contract areas and one APEI (separated by 240 to $1440 \mathrm{~km}$ ) were sampled along a sea surface primary productivity gradient from southeast to northwest across the eastern portion of the CCFZ nodule province (Martínez Arbizu and Haeckel, 2015). The four exploration contract areas were located within the eastern central subregion defined by Wedding et al. (2013), where an APEI did not fit. One of the nearest APEIs was thus sampled instead.

The aims of our study were (i) to test the hypotheses that support spatial conservation planning in the CCFZ, particularly the environmental drivers of alpha and beta diversity such as organic carbon fluxes to the seafloor and nodule density; (ii) to assess the representativeness of an APEI (i.e., APEI no. 3); and (iii) to improve the assessment of potential risks of biodiversity loss due to nodule mining. To tackle these issues, we focused on polychaete assemblages. Polychaetes are the dominant and most diverse group of the macrofauna; they can be quantitatively sampled and identified down to species level using a combination of morphological and molecular methods (Hessler and Jumars, 1974; Janssen et al., 2015; Wilson, 2017). Polychaetes also show a wide range of biological traits, from trophic behaviors to life history strategies, and play a major role in the functioning of benthic communities (Hutchings, 1998; Jumars et al., 2015).

\section{Materials and methods}

\subsection{Clarion-Clipperton Fracture Zone}

The CCFZ is located in the equatorial Pacific Ocean between the Clarion Fracture to the north and the Clipperton Fracture to the south and between Kiribati to the west and Mexico to the east (Fig. 1). This area covers about 6 million $\mathrm{km}^{2}$ and is composed of a high variety of habitats such as abyssal hills or seamounts, as well as polymetallic nodule fields (Glover et al., 2016). As part of the JPI Oceans project "Ecological aspects of deep-sea mining", the EcoResponse cruise SO239 took place from 11 March to 30 April 2015 aboard the RV Sonne (Martínez Arbizu and Haeckel, 2015). Sampling during the cruise focused on four exploration contract areas in addition to APEI number 3 (APEI no. 3; Fig. 1). All five study areas had water depths between 4000 and $5000 \mathrm{~m}$ (Fig. 1). The four exploration areas were licensed by the ISA to the Federal Institute for Geosciences and Natural Resources of Germany (BGR); the InterOceanMetal Joint Organization (IOM); the G-TEC Sea Mineral Resources NV (GSR); and the Institut Français de Recherche pour l'Exploitation de la Mer (Ifremer). Furthermore, the ISA administrates APEI no. 3 as part of the regional environmental plan for the CCFZ. The distances separating the areas ranged from $243 \mathrm{~km}$ (BGR to IOM) to $1440 \mathrm{~km}$ (BGR to Ifremer or APEI no. 3).

\subsection{Sampling strategy}

The sampling strategy resulted from a combination of objectives that were unique to each area, together with the overarching aim of describing alpha and beta diversity patterns across a productivity gradient that included both contract areas for nodule exploration and an APEI (Martínez Arbizu and Haeckel, 2015). In the BGR area, two sub-areas were sampled: a Prospective Area (PA) that could be mined in the future and a Reference Area (RA) that could serve as a preservation area. In the IOM area, three sub-areas were sampled: one that had been directly disturbed by a Benthic Impact Experiment (BIE; Radziejewska, 2002), one that had been impacted by the plume and one undisturbed control area. These levels of sampling stratification are, however, out of the scope of the present study, which focuses on variations between contract areas. After checking that there was no statistically significant difference in the abundance and richness of polychaetes between sub-areas, all samples within an area were deemed representative of that area and considered replicate samples. The level of replication within areas accordingly varied as a function of sampling stratification. The aim was to collect a minimum of five replicate samples per strata, but due to sampling failures and time constraints it could not be systematically achieved (Table 1).

Within each area, macrofaunal samples were collected using a United States Naval Electronics Laboratory (USNEL) spade box corer of $0.25 \mathrm{~m}^{2}$ (Hessler and Jumars, 1974). A total of 34 box cores were sampled, of which 30 samples were deemed quantitative (Table 1). The overlying water was siphoned and sieved using a sieve of $300 \mu \mathrm{m}$ mesh size. The box core sample surface was photographed, and all nodules were picked up from the sediment surface, washed with cold seawater over a $300 \mu \mathrm{m}$ mesh sieve and individually weighed. Sessile and crevice-inhabiting polychaetes, if present, remained with the nodules and were not considered in this study. According to Thiel et al. (1993), who washed and broke 26 nodules, the fraction of crevice inhabitant polychaetes has low significance and representativity (i.e., only 29 specimens belonging to six species) when compared with those living in sediments surrounding the nodules (i.e., 864 polychaetes). The upper $10 \mathrm{~cm}$ of each core was sliced into three layers $(0-3,3-5$ and $5-10 \mathrm{~cm})$ to facilitate sieving and sorting; each layer was transferred into cold 

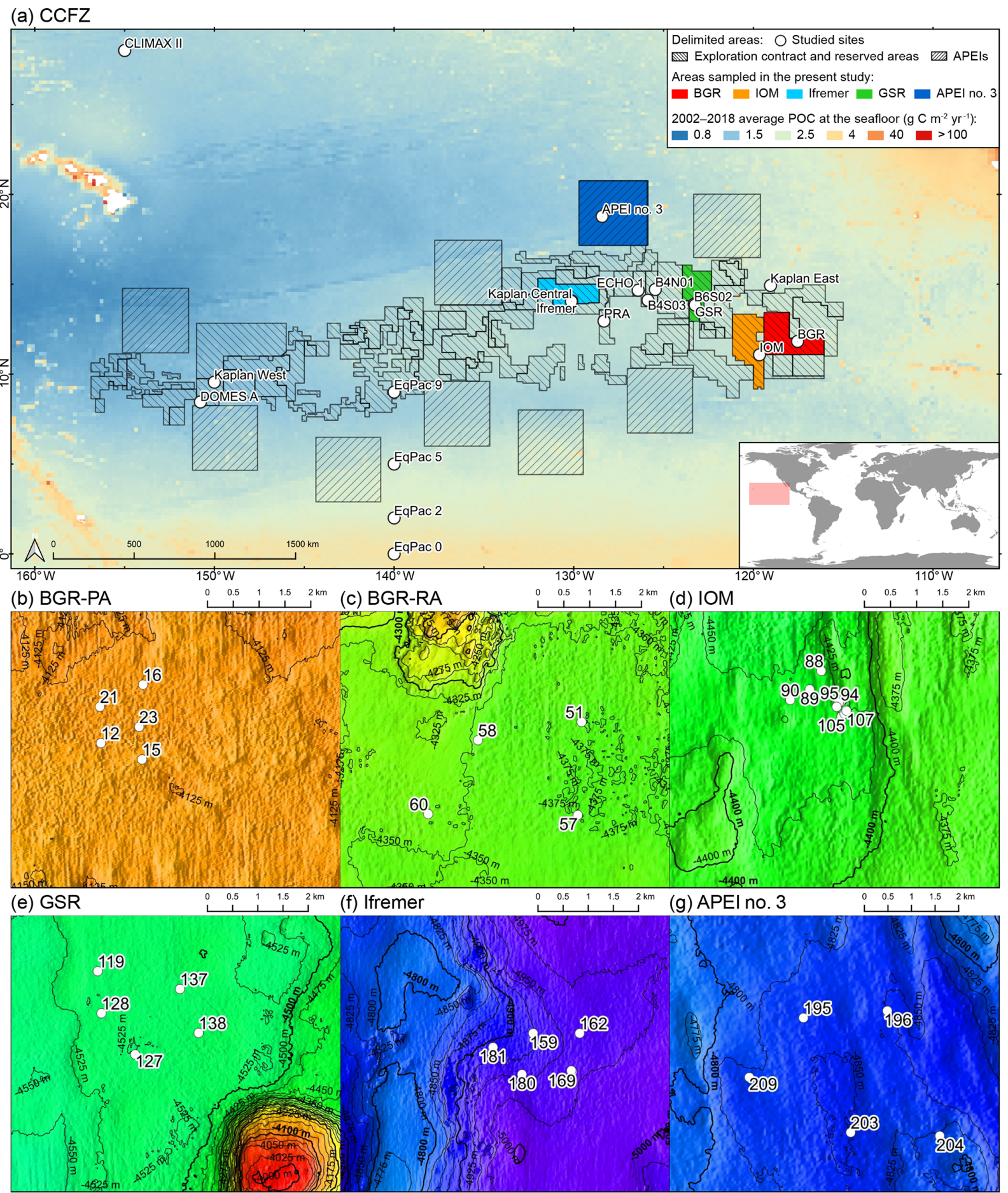

(f) Ifremer


0

2.81818

5.63636

Bathymetry (m)

8.45455

11.2727

14.0909

Figure 1. (a) Map of the nodule exploration contracts, reserved areas and Areas of Particular Environmental Interest (APEIs) in the ClarionClipperton Fracture Zone (CCFZ), showing the sampling areas from this study (in color) and previous macrobenthic surveys. The background map shows the average particulate organic carbon (POC) flux at the seafloor during the 2002-2018 period. The areas sampled during the SO239 cruises are enlarged in the following panels: BGR (b, c), IOM (d), GSR (e), Ifremer (f) and APEI no. 3 (g). Each has a detailed local hydroacoustic map based on the multibeam system EM122 (Martínez Arbizu and Haeckel, 2015; Greinert, 2016) in background. 
Table 1. Details of sampling, nodule density, total number of polychaete specimens (ind., individuals by box core) and number of polychaete species of all 34 box corer deployments across the CCFZ during the SO239 cruise. ${ }^{*}$ indicates box cores considered nonquantitative and thus not included in the analyses.

\begin{tabular}{|c|c|c|c|c|c|c|c|c|c|}
\hline Area & Locality & Station & $\begin{array}{r}\text { Date } \\
(\mathrm{dd} / \mathrm{mm} / \mathrm{yyyy})\end{array}$ & $\begin{array}{r}\text { Depth } \\
(\mathrm{m})\end{array}$ & Latitude & Longitude & $\begin{array}{r}\text { Nodule density } \\
\qquad\left(\mathrm{kg} \mathrm{m}^{-2}\right)\end{array}$ & $\begin{array}{r}\text { Total abundance } \\
\text { (ind. } 0.25 \mathrm{~m}^{-2} \text { ) }\end{array}$ & $\begin{array}{r}\text { Number of species } \\
\left(\operatorname{taxa} 0.25 \mathrm{~m}^{-2}\right)\end{array}$ \\
\hline BGR & BGR-PA & 12 & $20 / 03 / 15$ & 4118 & 11.8471667 & -117.05933 & 26.40 & 32 & 24 \\
\hline BGR & BGR-PA & 15 & $21 / 03 / 15$ & 4133 & 11.8443333 & -117.05217 & 26.80 & 67 & 40 \\
\hline BGR & BGR-PA & 16 & $21 / 03 / 15$ & 4122 & 11.8573333 & -117.052 & 24.00 & 52 & 34 \\
\hline BGR & BGR-PA & 21 & $22 / 03 / 15$ & 4120 & 11.8535 & -117.0595 & 22.80 & 43 & 28 \\
\hline BGR & BGR-PA & 23 & $22 / 03 / 15$ & 4122 & 11.85 & -117.05267 & 20.80 & 69 & 47 \\
\hline BGR & BGR-RA & $51^{*}$ & $27 / 03 / 15$ & 4348 & 11.8236667 & -117.52367 & 0.00 & 22 & 12 \\
\hline BGR & BGR-RA & 57 & $28 / 03 / 15$ & 4370 & 11.8075 & -117.52433 & 8.00 & 43 & 24 \\
\hline BGR & BGR-RA & 58 & $28 / 03 / 15$ & 4350 & 11.8205 & -117.54167 & 1.60 & 89 & 47 \\
\hline BGR & BGR-RA & 60 & $29 / 03 / 15$ & 4325 & 11.8076667 & -117.55033 & 18.00 & 65 & 48 \\
\hline IOM & IOM-control & 88 & $02 / 04 / 15$ & 4433 & 11.079 & -119.65883 & 0.00 & 53 & 33 \\
\hline IOM & IOM-control & 89 & $02 / 04 / 15$ & 4437 & 11.0758333 & -119.66083 & 1.20 & 38 & 29 \\
\hline IOM & IOM-control & 90 & $03 / 04 / 15$ & 4434 & 11.074 & -119.66417 & 0.00 & 42 & 24 \\
\hline IOM & IOM-disturb & 94 & $03 / 04 / 15$ & 4414 & 11.0736667 & -119.6555 & 0.40 & 38 & 28 \\
\hline IOM & IOM-disturb & 95 & $03 / 04 / 15$ & 4418 & 11.0735 & -119.65583 & 0.80 & 43 & 28 \\
\hline IOM & IOM-disturb & 97 & $04 / 04 / 15$ & 4421 & 11.0728333 & -119.65617 & 0.20 & 22 & 16 \\
\hline IOM & IOM-plume & $105^{*}$ & $05 / 04 / 15$ & 4423 & 11.0711667 & -119.65533 & 0.00 & 13 & 9 \\
\hline IOM & IOM-plume & 106 & $05 / 04 / 15$ & 4425 & 11.0716667 & -119.65483 & 0.20 & 23 & 18 \\
\hline IOM & IOM-plume & 107 & $05 / 04 / 15$ & 4425 & 11.0721667 & -119.6545 & 0.30 & 38 & 26 \\
\hline GSR & GSR & 119 & $08 / 04 / 15$ & 4516 & 13.8591667 & -123.25267 & 26.47 & 46 & 29 \\
\hline GSR & GSR & 127 & $09 / 04 / 15$ & 4514 & 13.8443333 & -123.246 & 27.10 & 59 & 32 \\
\hline GSR & GSR & 128 & $09 / 04 / 15$ & 4511 & 13.8516667 & -123.252 & 27.10 & 58 & 32 \\
\hline GSR & GSR & 137 & $11 / 04 / 15$ & 4510 & 13.856 & -123.238 & 25.20 & 60 & 34 \\
\hline GSR & GSR & 138 & $11 / 04 / 15$ & 4503 & 13.8481667 & -123.23467 & 26.47 & 74 & 48 \\
\hline Ifremer & Ifremer & 159 & $15 / 04 / 15$ & 4921 & 14.049 & -130.13433 & 19.80 & 30 & 23 \\
\hline Ifremer & Ifremer & 162 & $16 / 04 / 15$ & 4951 & 14.049 & -130.126 & 20.20 & 34 & 21 \\
\hline Ifremer & Ifremer & 169 & $17 / 04 / 15$ & 4964 & 14.0421667 & -130.12733 & 24.10 & 25 & 15 \\
\hline Ifremer & Ifremer & 180 & $18 / 04 / 15$ & 4936 & 14.0416667 & -130.13633 & 16.00 & 19 & 17 \\
\hline Ifremer & Ifremer & 181 & $18 / 04 / 15$ & 4896 & 14.0465 & -130.1415 & 16.80 & 38 & 27 \\
\hline Ifremer & Ifremer & 182 & $18 / 04 / 15$ & 4957 & 14.0423333 & -130.1275 & 22.40 & 19 & 13 \\
\hline APEI no. 3 & APEI no. 3 & 195 & $21 / 04 / 15$ & 4833 & 18.7958333 & -128.36217 & 6.28 & 4 & 3 \\
\hline APEI no. 3 & APEI no. 3 & 196 & $21 / 04 / 15$ & 4847 & 18.7971667 & -128.34617 & 1.80 & 7 & 5 \\
\hline APEI no. 3 & APEI no. 3 & $203^{*}$ & $23 / 04 / 15$ & 4843 & 18.774 & -128.35317 & 2.88 & 3 & 2 \\
\hline APEI no. 3 & APEI no. 3 & 204 & $23 / 04 / 15$ & 4816 & 18.77333333 & -128.33617 & 3.65 & 3 & 2 \\
\hline APEI no. 3 & APEI no. 3 & $209^{*}$ & $24 / 04 / 15$ & 4819 & 18.7845 & -128.3725 & 3.65 & 3 & 3 \\
\hline
\end{tabular}

seawater $\left(4^{\circ} \mathrm{C}\right)$ and sieved using the same mesh size. The 0 $3 \mathrm{~cm}$ layer was immediately sieved in the cold room with cold seawater $\left(4^{\circ} \mathrm{C}\right)$. The sieve residues from the overlying water and nodule washing were added to the $0-3 \mathrm{~cm}$ layer and live sorted. All polychaete specimens were photographed, individualized and preserved in cold $\left(-20^{\circ} \mathrm{C}\right) 80 \%$ ethanol and then kept at $-20^{\circ} \mathrm{C}$ (DNA-friendly). The $0-3 \mathrm{~cm}$ residue and $3-5$ and $5-10 \mathrm{~cm}$ layers were fixed in formalin for 48 to $96 \mathrm{~h}$, preserved in $96 \%$ ethanol, and later sorted in the laboratory (not DNA-friendly). All layers were combined for the community analysis. In the laboratory, from each DNA-friendly polychaete specimen and from very few fragments, a small piece of tissue was dissected, fixed in cold $96 \%$ ethanol and frozen at $-20^{\circ} \mathrm{C}$ for molecular studies. DNA sequences from fragments without a head were archived in BOLD and GenBank (Bonifácio et al., 2019) but were not further used for the purpose of this paper.

\subsection{DNA extraction, amplification, sequencing and alignment}

The DNA of the subsampled tissues was extracted using a NucleoSpin Tissue kit (Macherey-Nagel), following the manufacturer's protocol. Approximately 450 base pairs (bp) of $16 \mathrm{~S}, 700 \mathrm{bp}$ of COI (cytochrome c oxidase subunit I) and $1600 \mathrm{bp}$ of $18 \mathrm{~S}$ genes were amplified using the following primers: Ann16SF and 16SbrH for 16S (Palumbi, 1996; Sjölin et al., 2005); polyLCO, polyHCO, LCO1490, and HCO2198 for COI (Folmer et al., 1994; Carr et al., 2011); and 18SA, 18SB, 620F, and 1324R for $18 \mathrm{~S}$ (Medlin et al., 1988; Cohen et al., 1998; Nygren and Sundberg, 2003) for $18 \mathrm{~S}$. The polymerase chain reaction (PCR) mixtures of $25 \mu \mathrm{L}$ contained $5 \mu \mathrm{L}$ of Green GoTaq ${ }^{\circledR}$ Flexi Buffer (final concentration of $1 \mathrm{x}$ ), $2.5 \mu \mathrm{L}$ of $\mathrm{MgCl}_{2}$ solution (final concentration of $2.5 \mathrm{mM}$ ), $0.5 \mu \mathrm{L}$ of PCR nucleotide mix (final concentration of $0.2 \mathrm{mM}$ of each dNTP), $9.875 \mu \mathrm{L}$ of nuclease-free water, $2.5 \mu \mathrm{L}$ of each primer (final concentration of $1 \mu \mathrm{M}$ ), $2 \mu \mathrm{L}$ 
template DNA and $0.125 \mathrm{U}_{\text {of }}$ GoTaq $^{\circledR}$ G2 Flexi DNA Polymerase (Promega). The temperature profile for PCR amplification consisted of the following steps: initial denaturation at $95^{\circ} \mathrm{C}$ for $240 \mathrm{~s}, 35$ cycles of denaturation at $94^{\circ} \mathrm{C}$ for $30 \mathrm{~s}$, annealing at $52^{\circ} \mathrm{C}$ for $60 \mathrm{~s}$, extension at $72^{\circ} \mathrm{C}$ for $75 \mathrm{~s}$, and a final extension at $72^{\circ} \mathrm{C}$ for $480 \mathrm{~s}$. Particularly for COI, 40 cycles were run, and for $18 \mathrm{~S}$ extension during cycles lasted 180 s. PCR products, visualized after electrophoresis on $1 \%$ agarose gel, were sent to the MacroGen Europe Laboratory in Amsterdam (the Netherlands) to obtain sequences, using the same set of primers as used for the PCR.

Overlapping sequence (forward and reverse) fragments were aligned into consensus sequences using Geneious Pro 8.1.7 (2005-2015; Biomatters Ltd). For COI, the sequences were translated into amino-acid alignments and checked for stop codons to avoid pseudogenes. The minimum length coverage was $207 \mathrm{bp}$ for 16S, $327 \mathrm{bp}$ for COI and $1615 \mathrm{bp}$ for $18 \mathrm{~S}$.

The sequences were blasted in GenBank to check for the presence of contamination. Each set of genes was aligned separately using the following plugins: MAAFT (Katoh et al., 2002) for $16 \mathrm{~S}$ and $18 \mathrm{~S}$ and MUSCLE (Edgar, 2004) for COI. All sequences obtained in this study have been deposited in BOLD (http://www.boldsystems.org, last access: 12 February 2020; Ratnasingham and Hebert, 2007) or GenBank (http://www.ncbi.nlm.nih.gov/genbank/, last access: 12 February 2020).

\subsection{Taxonomic identification and feeding guilds classification}

Preserved specimens were examined under a Leica M125 stereomicroscope and a Nikon Eclipse E400 microscope, counted (anterior ends only) and morphologically identified using the deep-sea polychaete fauna bibliography (Fauchald, 1972, 1977; Böggemann, 2009) at the lowest taxonomic level possible (morphospecies). We separated closely related species (specimens that could not be discriminated morphologically) using the principle of phylogenetic species, whereby the genetic divergence among specimens belonging to the same species (intraspecific) is smaller than the divergence among specimens from different species (interspecific) (Hebert et al., 2003a). In the distribution of pairwise divergences among all sequences of a typical bar code dataset, a gap can be observed between intraspecific and interspecific variations. Molecular operational taxonomic units (MOTUs) were generally recognized using a threshold of $97 \%$ or $99 \%$ similarity between COI and $16 \mathrm{~S}$ sequences, respectively (Hebert et al., 2003a, b; Brasier et al., 2016). The similarity of sequences within species was considered when identifying morphologically similar species. As genetic data were only used to separate closely related species, the delimited taxa entities in the present study are referenced as morphospecies. Trophic guilds were determined at family level following Jumars et al. (2015).

\subsection{Environmental data}

Environmental data were compiled from Hauquier et al. (2019) and Volz et al. (2018). Sediment samples were collected with a multi-corer or a gravity corer during the same cruise and in the same areas (see Martínez Arbizu and Haeckel, 2015 for details). The sediment characteristics studied by Hauquier et al. (2019) included a clay fraction $(<4 \mu \mathrm{m})$, a silt fraction $(4-63 \mu \mathrm{m})$, total nitrogen (TN in weight \%), total organic carbon (TOC in weight \%) and chloroplastic pigment equivalents (CPEs in $\mu \mathrm{g} \mathrm{mL}^{-1}$ ). Nodules were weighed onboard for each box-core sample to calculate nodule density $\left(\mathrm{kg} \mathrm{m}^{-2}\right.$; Table 1). Particulate organic carbon flux (POC, $\mathrm{mg} \mathrm{C} \mathrm{m}^{-2} \mathrm{~d}^{-1}$ ) at the seafloor for our studied areas (eastern CCFZ) were provided by Volz et al. (2018). At the northeastern (NE)-Pacific-Basin scale, POC flux $\left(\mathrm{mg} \mathrm{C} \mathrm{m}^{-2} \mathrm{~d}^{-1}\right)$ at the seafloor was approximated using net surface primary production provided by the ocean productivity site (Westberry et al., 2008) averaged over the years 2002 to 2018 and applying the Suess algorithm (POC at the seafloor as a function of the net primary production scaled by depth; Suess, 1980; Table 2). POC flux at seafloor was considered a proxy for food supply to benthic communities.

\subsection{NE-Pacific-scale polychaete community data}

To put the results of our study in the larger context of the NE Pacific Basin, we compiled data from previous surveys of polychaete assemblages in the NE Pacific, including CLIMAX II sampled in 1969, DOMES A, B and C in 1977 and 1978, ECHO I in 1983, PRA in 1989, EqPac in 1992, Kaplan East in 2003, Kaplan West and Central in 2004, KR5 in 2012, 2013 and 2014 and GSRNOD15A (B4N01, B4S03 and B6S02) in 2015 (Paterson et al., 1998; Glover et al., 2002; Wilson, 2017; Smith et al., 2008b; De Smet et al., 2017). From these studies, we compiled (when available) the mean abundance (ind. $0.25 \mathrm{~m}^{-2}$ ), total number of species, ES163 and bootstrap (Table 2).

\subsection{Data analysis}

\subsubsection{Univariate analyses}

Abundance and number of species per box core (Table 1) and averaged by area (Table 2) were used as descriptors of alpha diversity. A few cryptic or damaged specimens that could not be classified to a lower taxonomical level were included in total abundance calculations but excluded from subsequent diversity analyses. To compare diversity among the studied areas and for all samples (eastern CCFZ), rarefaction curves were computed based on the total number of individuals and the total number of box core samples (Hurlbert, 1971; Gotelli and Colwell, 2001). Based on these data the expected number of species was calculated for 12 individuals (ES12) and 163 individuals (ES163), as 


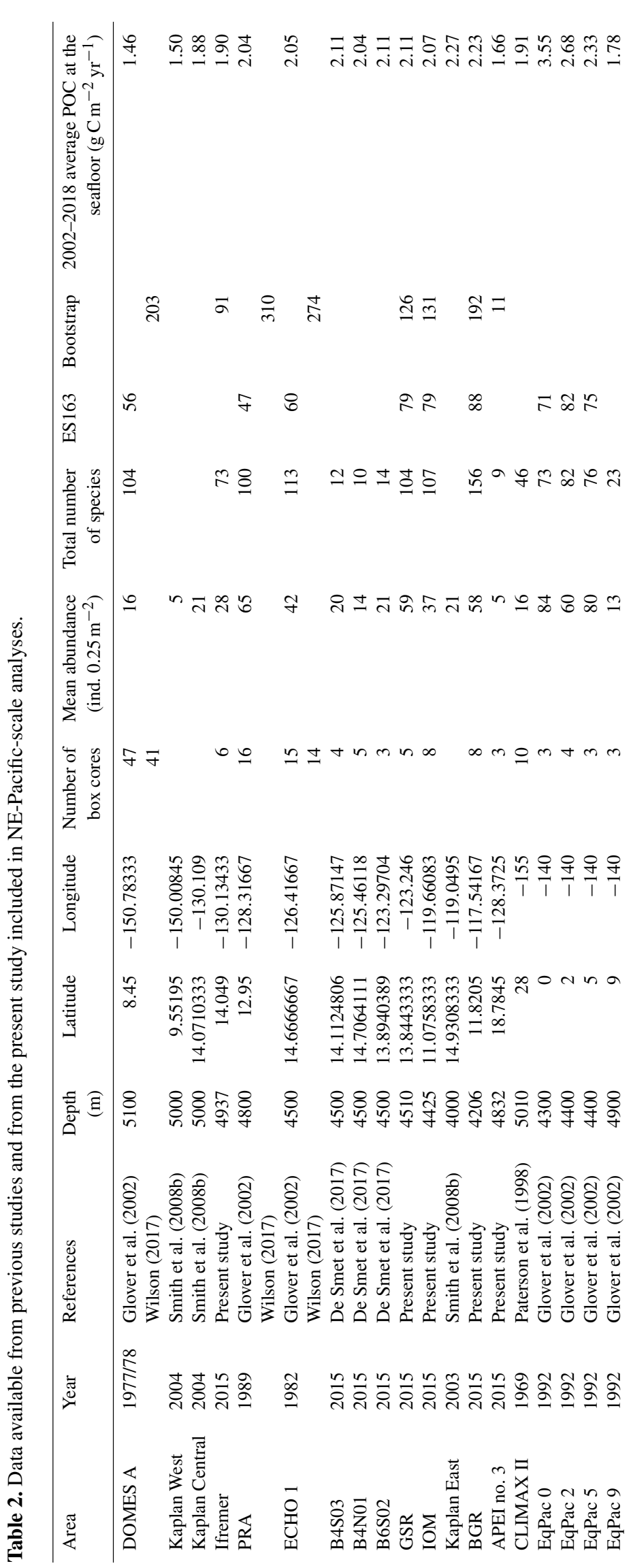

well as for three samples (S3). Nonparametric estimators of species richness were used to estimate the total number of species at local and regional scales. Abundance-based estimators included Chaol and abundance-based coverage estimator (ACE; O'Hara, 2005; Chiu et al., 2014). Incidencebased estimators included Chao2 (Chao, 1984), first- and second-order Jackknife (Burnham and Overton, 1979), and bootstrap (Smith and van Belle, 1984). A Venn diagram was used to show the distribution of rare, wide and common species across the CCFZ.

Univariate analyses relied on nonparametric tests. The Kruskal-Wallis rank sum test was used to test differences among areas (Hollander and Wolfe, 1973); and the Conover multiple pairs rank comparisons (adjusted $p$ value by Holm) was used to identify the pairs showing differences (Conover and Iman, 1979; Holm, 1979). Spearman correlations were sought between biotic and abiotic variables, using data from the SO239 cruise in the CCFZ and data compiled from the literature. The latter analysis aimed to test correlations between biotic variables and POC fluxes at the regional scale.

\subsubsection{Multivariate analyses}

Three indices of faunal similarity were used in multivariate analyses, the Chord-Normalized Expected Species Shared (CNESS), the New Normalized Expected Species Shared (NNESS; Trueblood et al., 1994; Gallagher, 1996) and the Jaccard family indices (Baselga, 2010; Legendre, 2014). The CNESS and NNESS were computed from probabilities of species occurrence in random draws of $m$ individuals, with low values of $m$ giving a high weight to dominant species and high values of $m$ giving a high weight to rare species. The best trade-off value of $m$ is the one providing the highest Kendall correlation between the similarity matrix for $m=1$ and the similarity matrix for $m=m$ max. The value of $m$ max was given by the total abundance of the least abundant sample considered. CNESS was the distance metric used to perform a redundancy analysis (RDA; Legendre and Legendre, 2012). The RDA is a constrained multivariate analysis that tested the influence of multiple environmental covariates on multi-specific assemblages. Species contributing significantly to the ordination were plotted out of the equilibrium circle in RDA (scaling 1). The best set of environmental variables was selected using a forward selection procedure (Borcard et al., 2011) among the environmental variables available (see Sect. 2.5): clay fraction, silt fraction, TN, TOC, CPE, nodule density and POC flux at the seafloor. Furthermore, when selected variables had more than $80 \%$ co-correlation, they were excluded, and the selection procedure was started over again. Also, the variance inflation factor (VIF) was used to verify the possible linear dependency among variables in the RDA model.

The NNESS index was used to perform a distance decay analysis in the same way as in Wilson (2017). Distance decay screens for a negative correlation between faunal 
similarities and geographic distances among pairs of areas. Wilson (2017) used the slope of linear regression between NNESS and distance to compute the rate of change (species $\mathrm{km}^{-1}$ ) and the species range (kilometers per species). The rate of change is the slope of linear regression between NNESS and distance multiplied by the mean total estimated species from all areas. The species range is the inverse of the rate of change.

The Jaccard family indices were used to partition betadiversity into its three components: similarity; turnover, which is dissimilarity due to species replacement, and nestedness, which is dissimilarity due to differences in the number of species (Baselga, 2010).

All analyses were conducted using the $\mathrm{R}$ language ( $\mathrm{R}$ Core Team, 2018) with RStudio (RStudio Team, 2015) and the following specific packages or functions: adespatial (Dray et al., 2019), BiodiversityR (Kindt and Coe, 2005), fossil (Vavrek, 2011), vegan (Oksanen et al., 2015), VennDiagram (Chen and Boutros, 2011), beta.div.comp (Legendre, 2014), ness (Menot, 2019).

\section{Results}

\subsection{Abundance and alpha diversity}

During the SO239 cruise, 1233 polychaete specimens were sampled in the five study areas. Interestingly, only a large specimen identified as Bathyasychis sp. 150 was found deeper than $50 \mathrm{~cm}$ (bottom of box core) and thus not included in the analyses. The dataset has been archived in the information system PANGAEA and is available in open access (Bonifácio et al., 2019).

The mean abundance in each study area tended to decrease from southeast to northwest, with high variability between neighboring areas (Fig. 2a). Mean densities ranged from $58 \pm 18$ ind. $0.25 \mathrm{~m}^{-2}$ in the BGR area to $5 \pm 2$ ind. $0.25 \mathrm{~m}^{-2}$ in APEI no. 3. The abundance per box core (Table 1) differed significantly between areas (Kruskal-Wallis test, $p<0.001)$. The pairwise comparison test (Conover-Holm) showed that (i) APEI no. 3 had significantly lower abundance than the other areas $(p \leq 0.01)$ except Ifremer, (ii) the Ifremer exploration area $\left(28 \pm 8\right.$ ind. $\left.0.25 \mathrm{~m}^{-2}\right)$ had significantly lower abundance than the BGR and GSR areas $(59 \pm 10$ ind. $\left.0.25 \mathrm{~m}^{-2}\right)(p<0.001)$, and (iii) the IOM area $(37 \pm 10$ ind. $\left.0.25 \mathrm{~m}^{-2}\right)$ had significantly lower $(p<0.01)$ abundance than the BGR and GSR areas. Furthermore, within the eastern CCFZ, the abundance per box core was significantly correlated (Spearman correlations; Fig. 3a) with the number of species (rho $=0.96, p<0.001, n=30$ ) and nodule density (rho $=0.36, p<0.05, n=30$ ); the mean abundance per area was significantly correlated only with POC flux at seafloor (rho $=0.90, p<0.05, n=5$; Fig. 3b). At the scale of the NE Pacific, polychaete abundances were also significantly corre- lated with POC flux at the seafloor (rho $=0.75, p<0.001$, $n=19$; Fig. 4a).

The polychaetes belonged to 41 families (Fig. 5a) with the most abundant being spionids (20\%), cirratulids (13\%), paraonids $(11 \%)$ and lumbrinerids $(6 \%)$. Spionids showed the highest relative abundance at the Ifremer (34\%), GSR $(27 \%)$ and IOM $(19 \%)$ areas, whereas cirratulids were dominant at APEI no. $3(36 \%)$ and the BGR (17\%) areas. The relative contributions of trophic guilds also varied among the areas (Fig. 5b). In particular, carnivores were more common at BGR, IOM and GSR $(23 \%-28 \%)$ than at Ifremer and APEI no. 3 (12\%-14\%), whereas deposit feeders were overwhelmingly dominant at Ifremer and APEI no. 3 (78\%$86 \%)$ and less so at BGR, IOM and GSR $(63 \%-65 \%)$. Suspension feeders, omnivores and scavengers contributed to less than $13 \%$ of abundance in each area and were not found in APEI no. 3.

Of the 1233 polychaetes, 1118 specimens belonging to 62 genera within 40 families were identified down to morphospecies. The 115 remaining specimens were too damaged, cryptic or doubtful to be assigned to a morphospecies and were thus not included in diversity and composition analyses. The DNA-friendly samples totaled 430 specimens, 265 of which were successfully barcoded with either the COI and 16S genes (or both). The success rates were $17 \%$ for COI and $60 \%$ for $16 \mathrm{~S}$. The COI gene was successfully sequenced for 71 specimens totaling 45 MOTUs; for the $16 \mathrm{~S}$ gene, 259 specimens were successfully sequenced covering $104 \mathrm{MO}-$ TUs; only 65 specimens were successfully sequenced using both genes and yielded 40 MOTUs. The $18 \mathrm{~S}$ gene was sequenced for phylogenetic purposes on a restricted number of specimens. The 21 sequences of the $18 \mathrm{~S}$ gene that have been obtained are mentioned here because they were archived concomitantly with COI and 16S sequences in GenBank and BOLD public datasets, but they are not further considered in this study.

Based on both morphological and molecular identification, a total of 275 morphospecies were recognized. The mean number of species per area tended to decrease from southeast to northwest with high variability between neighboring areas (Fig. 2b). Mean richness varied from $37 \pm 10$ taxa $0.25 \mathrm{~m}^{-2}$ in BGR to $3 \pm 2$ taxa $0.25 \mathrm{~m}^{-2}$ in APEI no. 3 . The number of species per box core (Table 1) differed significantly among areas (Kruskal-Wallis test, $p<0.001$ ). The pairwise comparison test (Conover-Holm) showed that the number of species per box core was (i) significantly lower at APEI no. 3 than all other areas $(p \leq 0.01)$ except Ifremer, (ii) significantly lower at Ifremer $\left(19 \pm 5\right.$ taxa $\left.0.25 \mathrm{~m}^{-2}\right)$ than at BGR and GSR $\left(35 \pm 7\right.$ taxa $\left.0.25 \mathrm{~m}^{-2}\right)(p<0.001)$, and (iii) significantly lower at IOM $\left(25 \pm 6\right.$ taxa $\left.0.25 \mathrm{~m}^{-2}\right)$ $(p<0.05)$ than at BGR and GSR. A total of 156 species (observed species richness, Sobs) were sampled at BGR from eight box core samples, 107 species at IOM from eight box cores, 104 species at GSR from five box cores, 73 species at Ifremer from six box cores and 9 species at APEI no. 3 

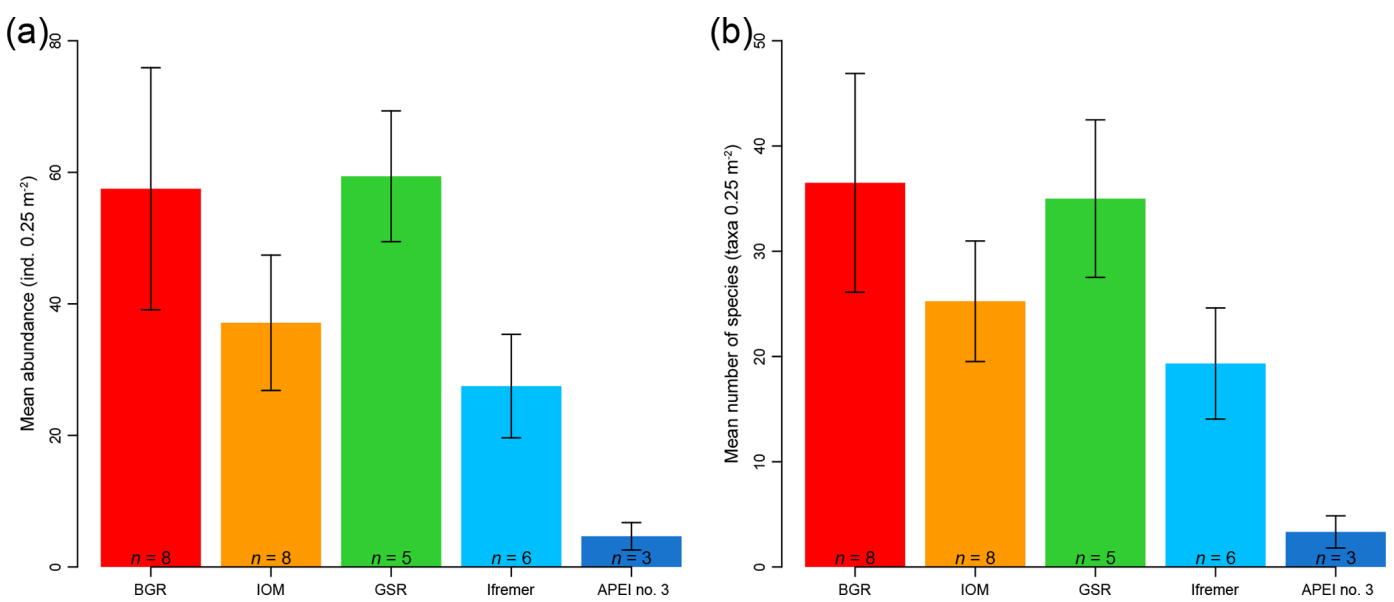

Figure 2. Bar plots of mean abundance per area (a) and mean species richness per area (b) of polychaete assemblages for each sampled area within the eastern CCFZ. $n$ indicates the number of box cores samples. Error bars show the standard deviation.

from three box cores (Table 3). Species rarefaction curves, based on individuals or samples, did not reach an asymptote at the local scale (Fig. 6a, b). Individual-based rarefaction curves did not show any clear diversity patterns among study areas (Fig. 6a). Sample-based rarefaction curves followed a pattern similar to abundance (Fig. 6b). From a random draw of three box cores, BGR and GSR, with 82 and 77 species, respectively, had higher expected numbers of species than IOM and Ifremer did, with 58 and 45 species, respectively. APEI no. 3, with only 9 species, had the lowest expected number of species (Fig. 6b, Table 3). The nonparametric estimators of local diversity followed the same patterns with the highest values for BGR and the lowest for APEI no. 3 (Table 3).

Within the eastern CCFZ, the mean number of species in each study area was significantly correlated (Spearman correlations; Fig. 3b) with POC flux at seafloor $(\mathrm{rho}=1.00$, $p<0.001, n=5$ ) and CPE (rho $=0.90, p<0.05, n=5$ ). At the scale of the NE Pacific, neither ES163 (rho $=0.59$, $p=0.09, n=9$ ) nor bootstrap (rho $=0.10, p=0.8, n=8$ ) were correlated with POC flux at the seafloor (Fig. 4b, c).

\subsection{Beta and gamma diversity}

In the RDA, the forward selection procedure kept CPE, clay fraction and nodule density as the best explanatory variables. The model explained $13 \%\left(R_{\text {adj }}^{2}\right)$ of the total variance in the composition of polychaete assemblages (Fig. 7a). The first axis of the RDA discriminated the eastern areas (BGR, IOM and GSR) from the western areas (Ifremer and APEI no. 3). The second axis of the RDA discriminated Ifremer from APEI no. 3 but also captured local-scale variation because replicate samples within areas were distributed along this second axis. The CPE concentrations mostly explained variance along the first axis. CPE was also positively and highly correlated with POC flux at seafloor and TOC (Fig. 3b).
The first axis of the RDA thus illustrates the influence of food inputs on species composition. The clay fraction contributed to the first and the second axis of the RDA. Grain size distribution differentiated APEI no. 3 from all other areas in the CCFZ (see Hauquier et al., 2019, for details). In the RDA, the clay fraction accounted for the large dissimilarity in species composition of the APEI no. 3. Nodule density was the main contributor to the second axis of the RDA. Variation in nodule density likely accounted for some of the local variation in species composition. The ordination of species (Fig. 7b) showed that Lumbrinerides sp. 2107 was the species most characteristic of the eastern areas; a cirratulid (Aphelochaeta sp. 2062) and a maldanid (Maldanidae sp. 121) were characteristic of APEI no. 3; and two spionids (Aurospio sp. 249 and Laonice sp. 349), a paraonid (Levinsenia sp. 498), and an opheliid (Ammotrypanella sp. 2045) were characteristic of the Ifremer area.

The distance decay of similarity showed two different patterns (Fig. 8a, b). APEI no. 3 had very low values of NNESS compared with all other areas, irrespective of distance (Fig. 8a). There was no statistically significant correlation between NNESS and distance $\left(R_{\mathrm{adj}}^{2}=18 \%, p=\right.$ 0.12). However, without APEI no. 3, the NNESS values among pairs of exploration contract areas (Fig. 8b) within the CCFZ per se were negatively correlated with distance $\left(R_{\mathrm{adj}}^{2}=0.85, p=0.006\right)$. The slope of the linear regression $(-0.0003)$ multiplied by the mean of species richness estimators for each area (Table 3) provided a rate of species change that ranged from 0.04 species km${ }^{-1}$ with the bootstrap estimator (mean species richness of 135 species) to 0.07 species km$~^{-1}$ for the ACE estimator (mean species richness of 234 species). The inverse of these rates of species change predicted geographic ranges of 14 to $25 \mathrm{~km}$.

Beta diversity was thus high across the CCFZ, particularly between the exploration contract areas, south of the Clarion Fracture Zone, and APEI no. 3, north of the Clar- 

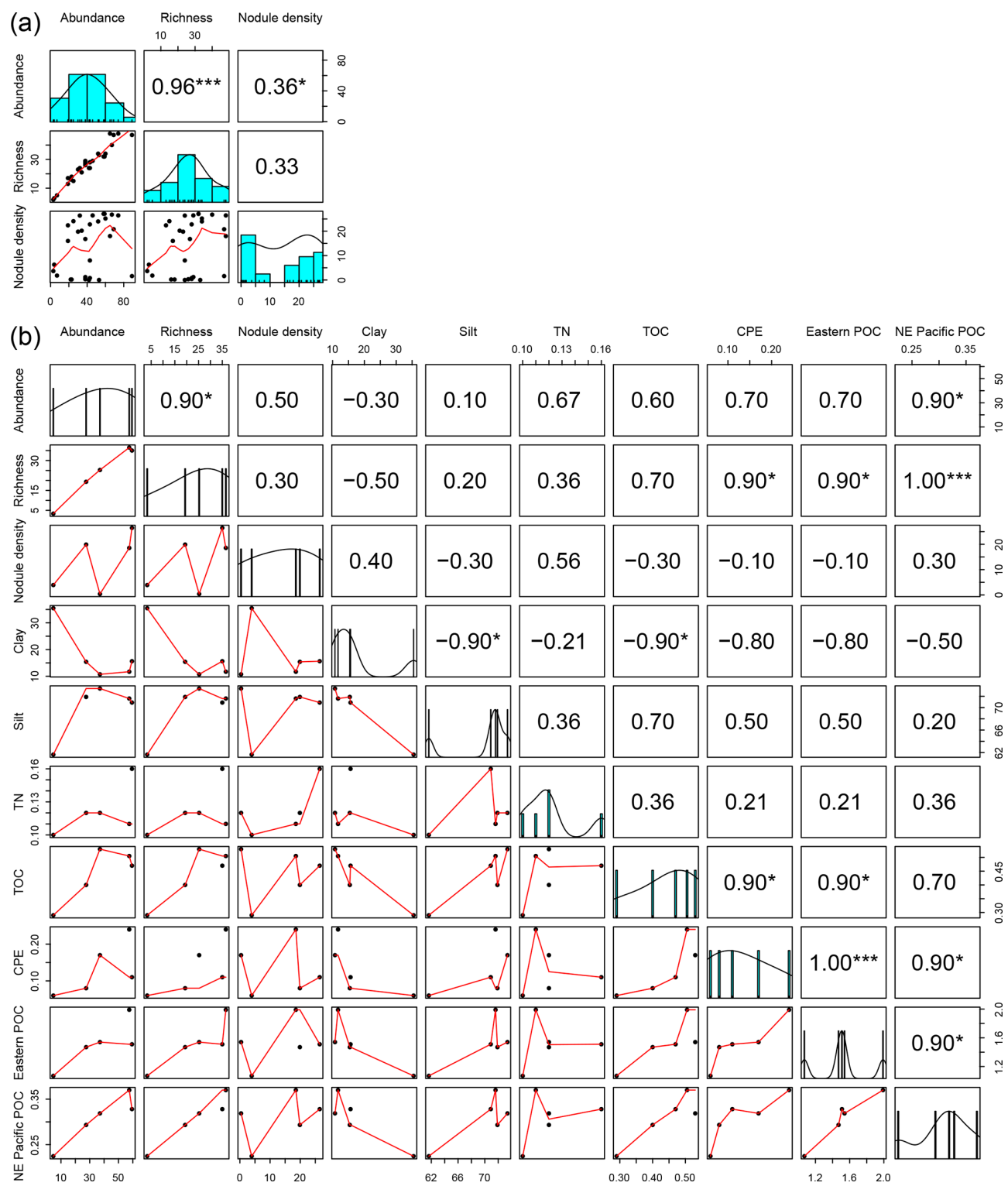

Figure 3. Correlation matrix between biotic and abiotic variables from sampled areas within the eastern CCFZ. Diagonal plots (a, b) show the distribution frequency of values for each variable. Panels below the diagonal plots $(\mathbf{a}, \mathbf{b})$ show the correlation plot between pairs of variables. Panels above the diagonal (a, b) plots show the Spearman coefficient correlations between pairs of variables. Abundance, richness and nodule density per box core are shown in (a) and average biotic and abiotic variables per area are shown in (b). Eastern POC values provided by Volz et al. (2018); NE Pacific POC values were estimated in the present study. ${ }^{*}$ indicates $p<0.05,{ }^{* *}$ " $p<0.01$ and ${ }^{* * *} p<0.001$.

Table 3. Observed species richness (Sobs) and estimators of species richness for each sampled area and for the eastern CCFZ.

\begin{tabular}{|c|c|c|c|c|c|c|c|c|c|c|c|}
\hline \multirow[t]{2}{*}{ Area } & \multirow[t]{2}{*}{ Sobs } & \multicolumn{4}{|c|}{ Individual-based } & \multicolumn{6}{|c|}{ Sample-based } \\
\hline & & $n$ & Chao1 & ACE & ES12 & $n$ & Chao2 & $\begin{array}{r}\text { Jackknife first } \\
\text { order }\end{array}$ & $\begin{array}{r}\text { Jackknife second } \\
\text { order }\end{array}$ & Bootstrap & S3 \\
\hline BGR & 156 & 415 & $355 \pm 61$ & $334 \pm 11$ & $11 \pm 1$ & 8 & $311 \pm 46$ & $240 \pm 34$ & 295 & $192 \pm 15$ & $82 \pm 9$ \\
\hline IOM & 107 & 274 & $191 \pm 30$ & $225 \pm 10$ & $11 \pm 1$ & 8 & $182 \pm 26$ & $162 \pm 22$ & 195 & $131 \pm 10$ & $58 \pm 6$ \\
\hline GSR & 104 & 263 & $157 \pm 19$ & $196 \pm 9$ & $11 \pm 1$ & 5 & $161 \pm 20$ & $153 \pm 26$ & 178 & $126 \pm 12$ & $77 \pm 6$ \\
\hline Ifremer & 73 & 154 & $163 \pm 38$ & $181 \pm 8$ & $11 \pm 1$ & 6 & $160 \pm 36$ & $115 \pm 19$ & 142 & $91 \pm 9$ & $45 \pm 5$ \\
\hline APEI no. 3 & 9 & 12 & $20 \pm 10$ & $27 \pm 2$ & $9 \pm 0$ & 3 & $30 \pm 27$ & $14 \pm 4$ & 17 & $11 \pm 2$ & $9 \pm 0$ \\
\hline CCFZ & 275 & 1118 & $450 \pm 41$ & $484 \pm 13$ & $11 \pm 1$ & 30 & $467 \pm 44$ & $411 \pm 29$ & 498 & $334 \pm 14$ & $66 \pm 13$ \\
\hline
\end{tabular}


(a) Mean abundance (ind. $0.25 \mathrm{~m}^{-2}$ ) **

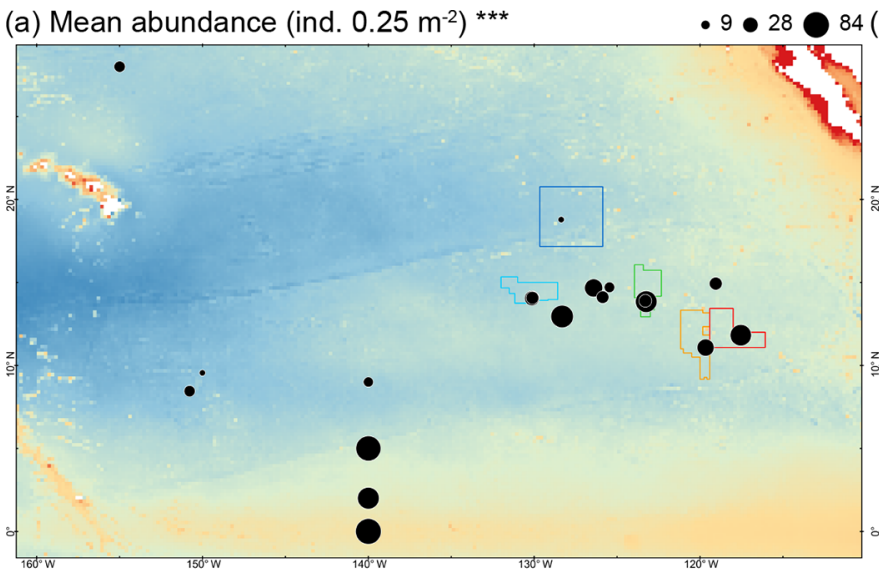

\section{(c) Bootstrap}

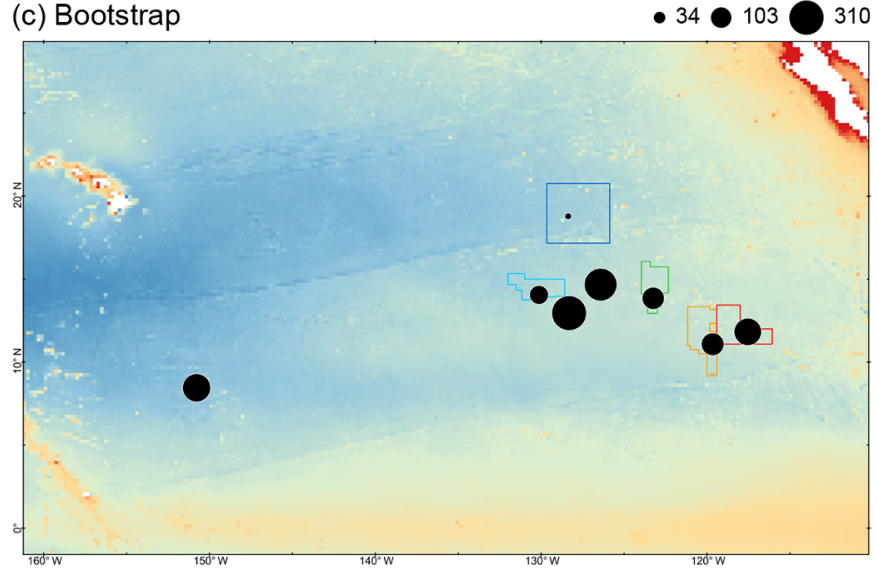

(b) ES163

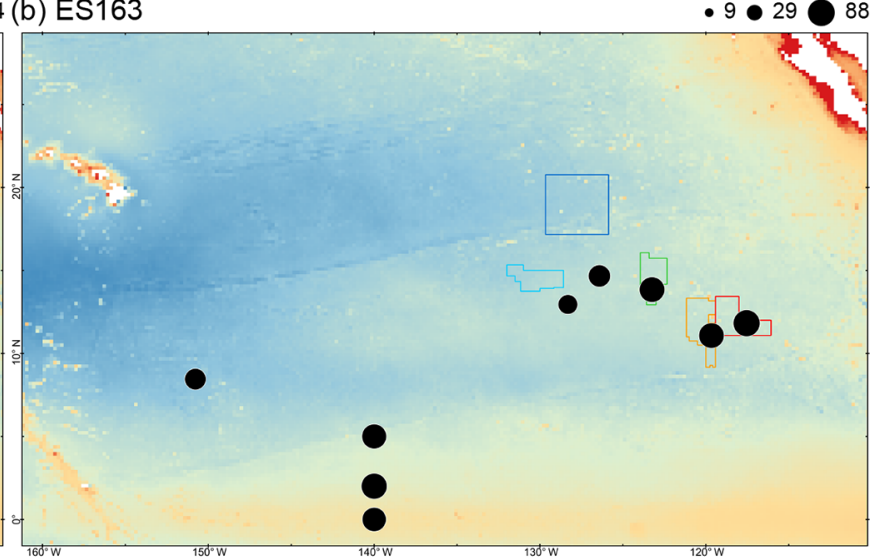

Areas sampled in the present study:

$\square$ BGR $\square$ IOM $\square$ Ifremer $\square$ GSR $\square$ APEI no. 3

2002-2018 average $P O C$ at the seafloor $\left(\mathrm{g} \mathrm{C} \mathrm{m}^{-2} \mathrm{yr}^{-1}\right)$ :

$\begin{array}{llllll}0.8 & 1.5 & 2.5 & 4 & 40 \square>100\end{array}$

Figure 4. Plot of mean abundance (a) and diversity estimators, ES163 (b) and bootstrap (c), from previous studies and the present study (Table 2) in relation to the 2002-2018 average particulate organic carbon (POC) flux at the seafloor along the CCFZ (background). *** indicates significant $(p<0.001)$ Spearman correlation.

ion Fracture Zone. In addition, the decomposition of beta diversity showed that dissimilarity was mainly due to species turnover $(91 \%)$ and not nestedness $(9 \%)$. However, species turnover was driven by singletons. The Venn diagram (Fig. 9) showed that, in each area, at least $30 \%$ and up to $67 \%$ of species were unique to one area, so that overall 169 out of 275 species were unique to a given area. Of these, 134 species were singletons (i.e., morphospecies known from a single specimen). Only a single species, Aurospio sp. 249, was sampled in all five areas, 16 species $(6 \%)$ were sampled in four areas, 33 species (12\%) were shared among three areas and 56 species $(20 \%)$ were shared between two areas.

When all individuals and samples were pooled together, rarefaction curves did not level off (Fig. 10a, b) and the number of singletons steadily increased with increasing sample size (Fig. 10b). At this regional scale, nonparametric estimators of species richness ranged from 334 to 498 species (Table 3).

\section{Discussion}

\subsection{Major forces driving local- and regional-scale patterns in community structure and composition}

Food supply, sediment grain size and the density of nodules are the three main environmental factors that seem to drive the structure and composition of polychaete assemblages in the CCFZ.

The abundance of polychaetes per box core was positively correlated with nodule density, which is consistent with previous studies showing that nodules enhance macrofaunal densities and polychaete diversity (De Smet et al., 2017; Yu et al., 2018). Nodules may have antagonistic influences on different size groups of benthic communities. Meiofaunal assemblages are less abundant in nodule-rich sediments than in nodule-free sediments, which may be due to the lower volume of sediment available in nodule areas (Miljutina et al., 2010; Hauquier et al., 2019). In our study, the volume and surface occupied by nodules were not quantified but the positive relationship between nodule density and polychaete abundance shows that space is not a limiting 
(a)

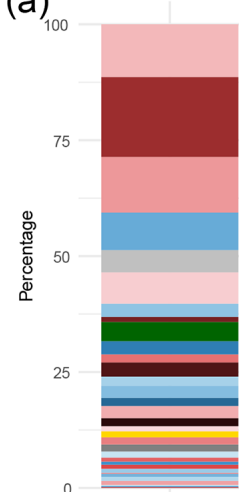

BGR

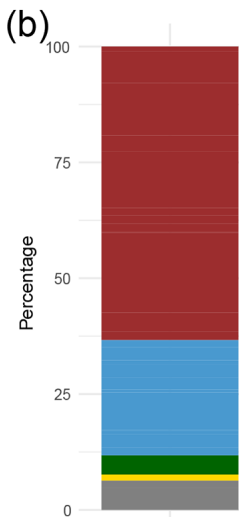

BGR

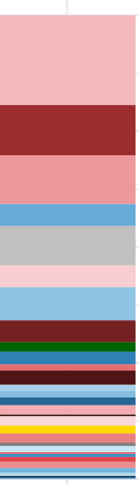

IOM

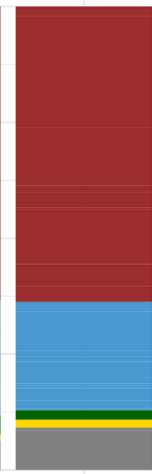

IOM

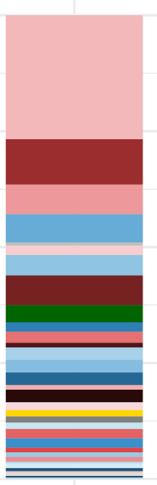

GSR

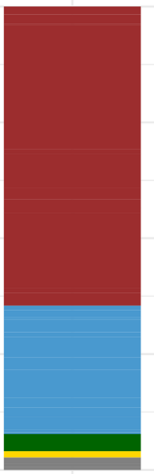

GSR

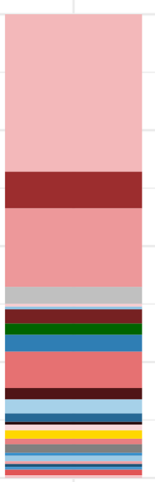

Ifremer

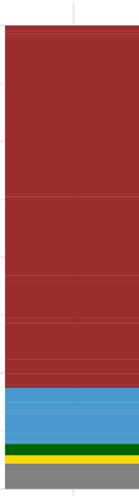

Ifremer

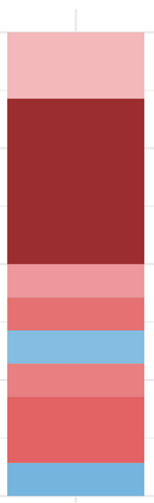

APEl no. 3

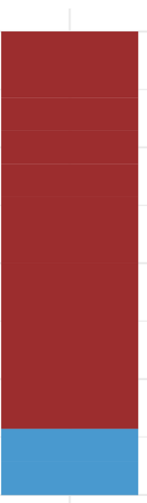

APEI no. 3
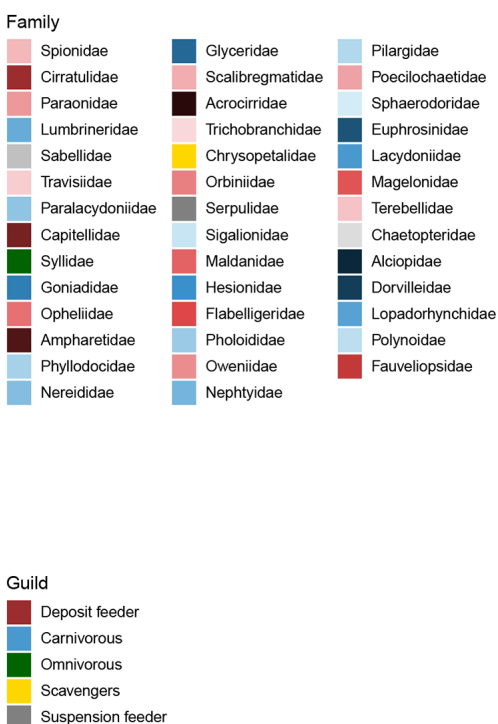

Figure 5. Bar plots of the relative abundance of families (a) and trophic guilds (b) for each sampled area within the eastern CCFZ. Gradient color in (a) corresponds to the different guilds in (b).
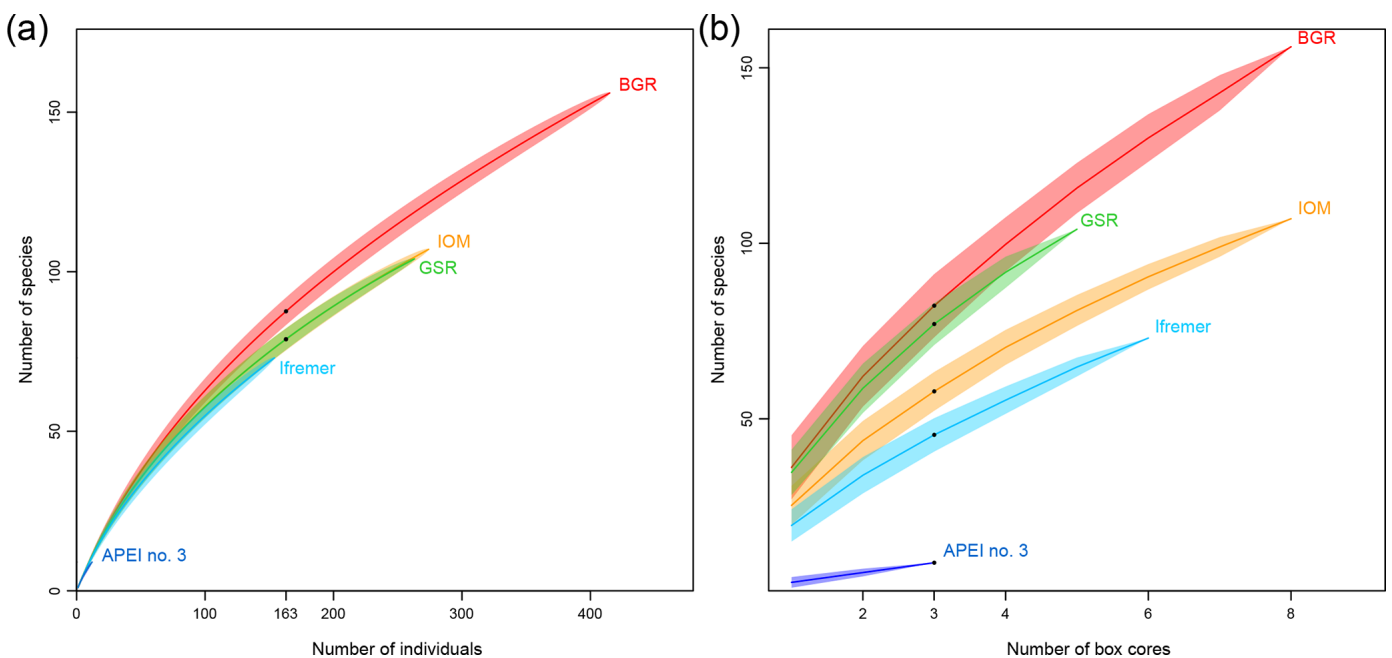

Figure 6. Rarefaction curves based on individuals (a) and samples (b) for each sampled area within the eastern CCFZ.

factor for polychaetes. Nodules also increase habitat heterogeneity, providing hard substrate for sessile organisms and generally enhancing the standing stocks of both sessile and vagile megafauna (Amon et al., 2016; Vanreusel et al., 2016; Simon-Lledó et al., 2019). Nodules increase seafloor rough- ness, thereby increasing friction (Sternberg, 1970; Boudreau and Scott, 1978) and potentially sediment deposition rates. The large sessile suspension feeders may similarly enhance biodeposition (Graf and Rosenberg, 1997). Both processes may decelerate water current, stabilizing sediments and thus 

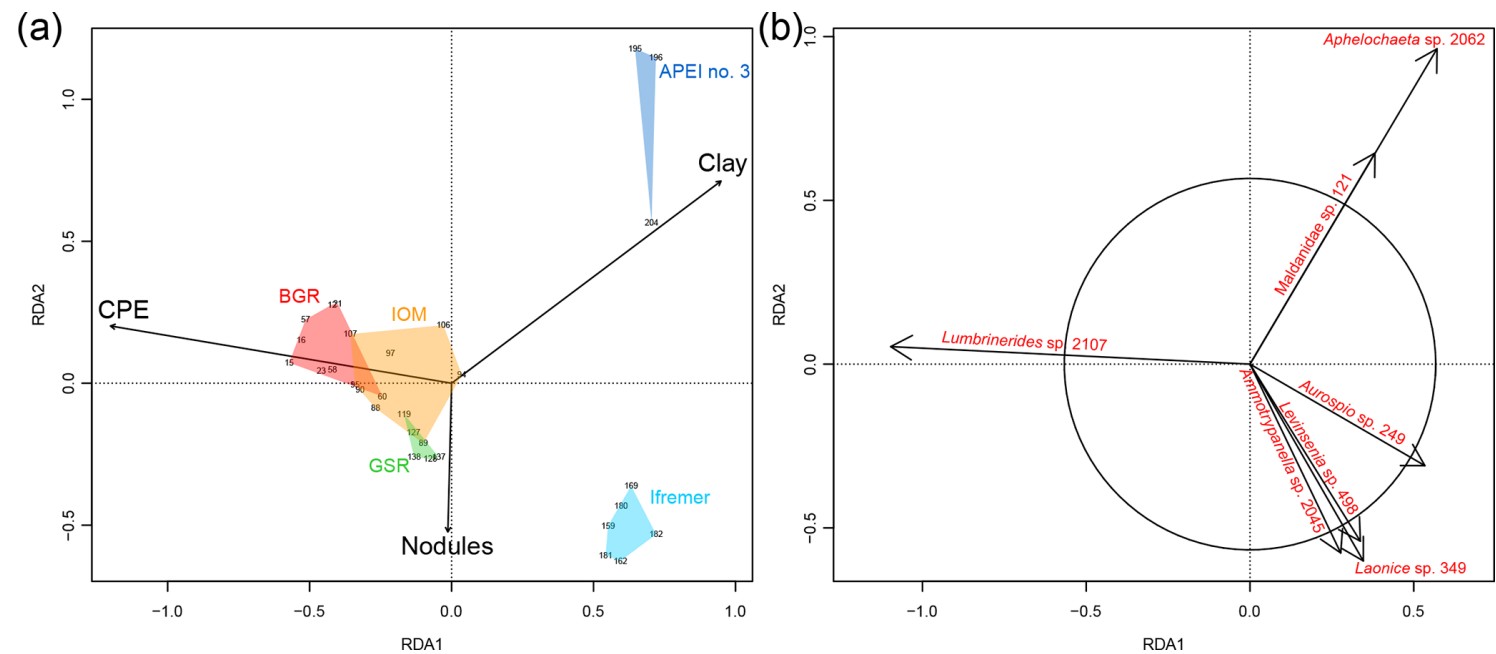

Figure 7. Redundancy analysis (RDA) biplot based on the Chord-Normalized Expected Species Shared (CNESS) distance constrained by the selected variables (a, scaling 2) and showing species significantly contributing to the ordination diagram (b, scaling 1).
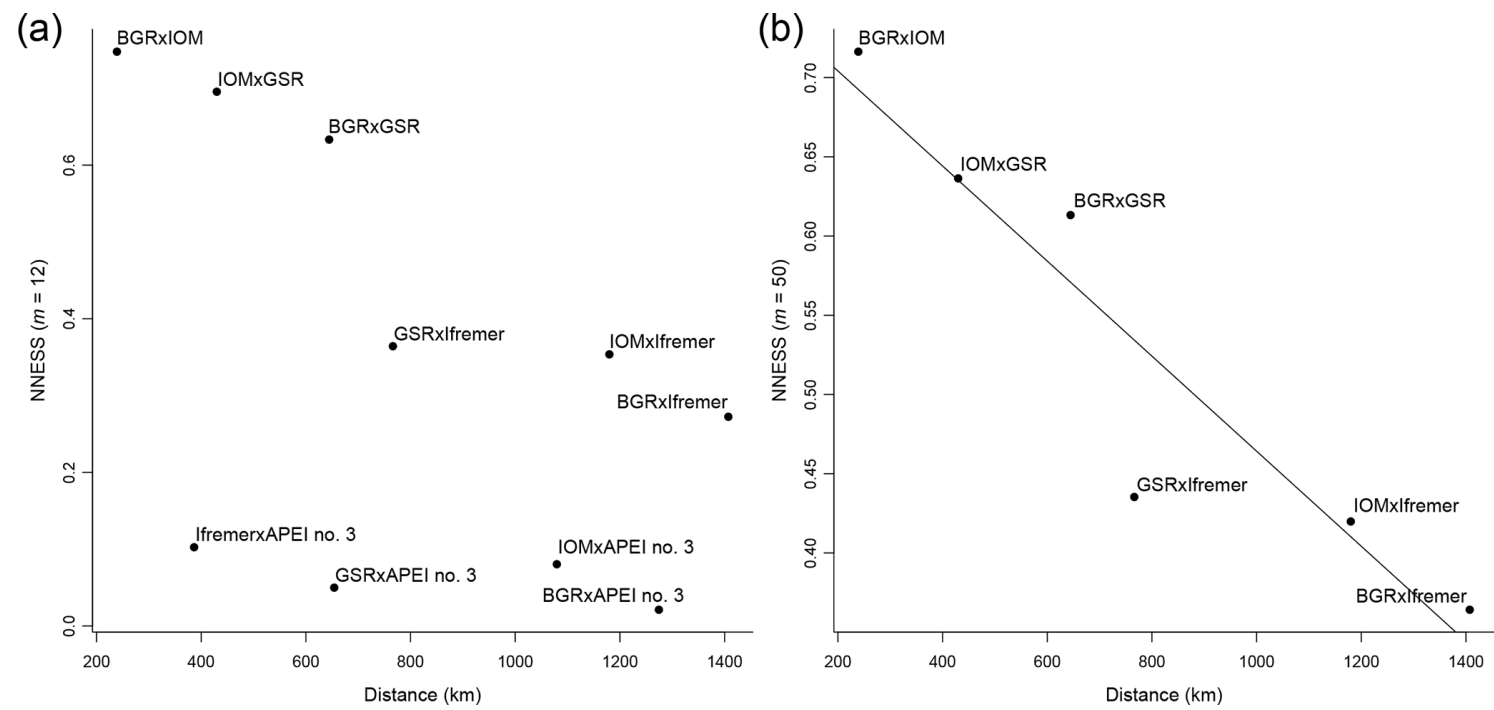

Figure 8. Distance decay of New Normalized Expected Species Shared (NNESS) between BGR, IOM, GSR, Ifremer, and APEI no. 3 using $m=12$ (a) and between BGR, IOM, GSR, and Ifremer using $m=50$ with regression ( $y$ intercept: 0.7642, slope: -0.0002999$)$ (b).

increasing organic carbon supply in the same ways that polychaete tube lawns do, for example (Friedrichs et al., 2000). An increase in food supply may explain the higher densities of polychaetes in nodule-rich areas.

At regional to global scales, food input is among the main forcing factors of the structure and function of the abyssal ecosystem, which mainly rely upon $0.5 \%-2 \%$ of the organic carbon derived from sea surface primary production (Rowe et al., 1991; Smith et al., 1997; Smith et al., 2008a). Variations in sea surface primary productivity divide the NE Pacific abyss into three main areas (Sokolova, 1997; Hannides and Smith, 2003; Smith and Demopoulos, 2003): the eutrophic abyss in the equatorial upwelling zone $\left(-5^{\circ} \mathrm{S}-5^{\circ} \mathrm{N}\right)$, with POC flux of about $1-2 \mathrm{~g} \mathrm{C} \mathrm{m}^{-2} \mathrm{yr}^{-1}$; the mesotrophic abyss in the equatorial northern Pacific $\left(5-15^{\circ} \mathrm{N}\right)$, with a POC flux of about $0.5-1.5 \mathrm{~g} \mathrm{C} \mathrm{m}^{-2} \mathrm{yr}^{-1}$; and the oligotrophic abyss underlying the North Pacific Subtropical Gyre $\left(15-35^{\circ} \mathrm{N}\right)$, with a POC flux lower than $0.5 \mathrm{~g} \mathrm{C} \mathrm{m}^{-2} \mathrm{yr}^{-1}$. Our metadata analysis confirmed that polychaete abundance was significantly and positively correlated with POC flux at seafloor, distinguishing areas in the oligotrophic abyss (APEI no. 3, CLIMAX II, DOMES A, EqPac 9 and Kaplan West) with low abundance (4-21 ind. $0.25 \mathrm{~m}^{-2}$ ) from areas in the mesotrophic abyss (Kaplan Central, Ifremer, PRA, ECHO 1, GSRNOD15A, GSR, IOM, Kaplan East and BGR) with average to high abundance (14-85 ind. $0.25 \mathrm{~m}^{-2}$ ) and areas in the eutrophic abyss (EqPac 0, 2 and 5) with abundance in the highest range (60-84 ind. $0.25 \mathrm{~m}^{-2}$; see Table 2). 


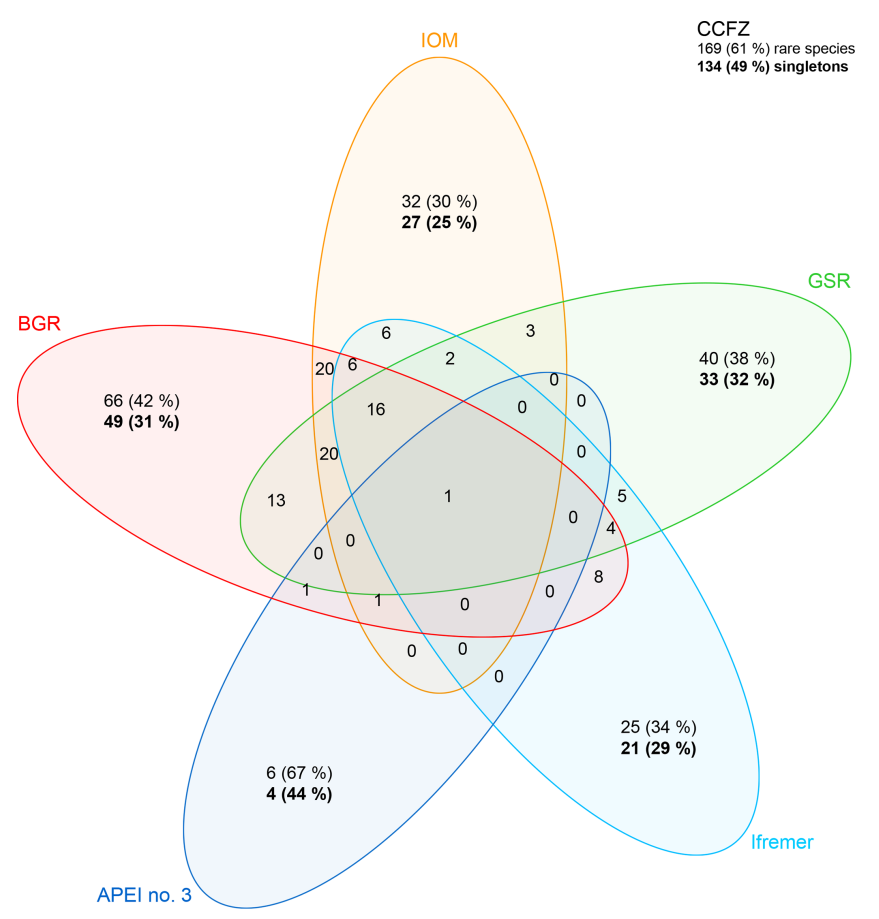

Figure 9. Venn diagram with the records of rare (being recorded in only one area, with corresponding percentage) and common species among sampled areas and for the eastern CCFZ. Bold values indicate the number of species with a single specimen (singletons, with corresponding percentage).

The exploration areas sampled in our study all lie within the mesotrophic zone, but APEI no. 3 lies within the oligotrophic zone. An analysis of biogeochemical processes confirmed the very low POC fluxes to the seafloor at APEI no. 3 $\left(1 \mathrm{mg} \mathrm{C} \mathrm{m}^{-2} \mathrm{~d}^{-1}\right)$ and found respiration rates that were 2 fold lower than in the exploration areas of the mesotrophic zone (Volz et al., 2018). APEI no. 3 was also characterized by higher clay content, which may be caused by lower sedimentation rate and a different sedimentation regime (Hauquier et al., 2019; Volz et al., 2018). Polychaete assemblages in APEI no. 3 consistently showed lower abundance, lower species richness and lower alpha diversity. Species turnover was also very high, with APEI no. 3 showing the highest rate of species unique to an area and the lowest NNESS for all pairs of comparisons. The redundancy analysis also suggested that, in addition to food supply, the higher relative proportion of clay contributed to variation in species composition at APEI no. 3. The polychaete assemblage was dominated by cirratulids, with one species significantly contributing to ordination (Aphelochaeta sp. 2062). Some cirratulids are recognized as surface deposit feeders (Jumars et al., 2015) and may prefer the smaller particles predominantly present at APEI no. $3\left(D_{4-3}=15.71 \mu \mathrm{m}\right)$. At least two cirratulid species can effectively select particle sizes in the clay size range using their tentacles (Magalhães and Bailey-Brock, 2017). The strong shift in community struc- ture and composition of polychaete assemblages between the APEI no. 3 and the exploration areas echoes that of megafaunal (Vanreusel et al., 2016), nematode (Hauquier et al., 2019) and tanaid assemblages (Błażewicz et al., 2019). The biogeochemical settings and the biological patterns of the three size groups of the benthic fauna thus converge to conclude that the structure and functioning of the benthic ecosystem in APEI no. 3 is not representative of any of the four exploration contract areas included in this study.

Within the mesotrophic zone, the species composition of polychaete assemblages in the Ifremer exploration area differed from the other exploration areas. Differences were driven by species belonging to common deep-sea deposit feeders such as spionids, paraonids and opheliids (Jumars et al., 2015), whereas a lumbrinerid species characterized the eastern exploration areas (BGR, IOM and GSR). Furthermore, other carnivorous families were relatively more abundant in the eastern areas as well, such as paralacydoniids and sigalionids. These results agree with Smith et al. (2008b) who observed higher abundances of lumbrinerids and amphinomids, two families of carnivorous polychaetes (Jumars et al., 2015), in the eastern CCFZ (Kaplan East). The upper trophic levels indeed tended to be less represented in the Ifremer and APEI no. 3 areas than in the eastern areas. This pattern matches model predictions that food chain length is positively correlated with resource availability in very low productivity systems $\left(<1-10 \mathrm{~g} \mathrm{C} \mathrm{m}^{-2} \mathrm{yr}^{-1}\right.$; Moore and de Ruiter, 2000; Post, 2002). McClain and Schlacher (2015) formulated this food chain length-productivity relationship as the "one-more-trophic-level" hypothesis to account for a positive productivity-diversity relationship. Species richness and productivity were significantly correlated at eastern CCFZ scale, but no significant correlation was found between alpha diversity and productivity in the meta-analysis at the scale of the NE Pacific. The reason diversity and productivity were not correlated in the meta-analysis, which included data from the literature, could be mainly methodological. In particular, the use of integrative taxonomy in this study versus morphological taxonomy in previous works might hinder comparisons of diversity metrics.

To conclude, our study supports the assumptions behind the creation of nine large APEIs, namely that gradients of sea surface primary productivity determine large-scale patterns and that nodule densities determine local-scale patterns in community structure, species composition and functioning (Wedding et al., 2013). However, among exploration contract areas, there is a shift in community composition and trophic structure between BGR, IOM, and GSR on the one hand and Ifremer on the other hand, suggesting that these two groups do not belong to the same subregion, as hypothesized by Wedding et al. (2013). Environmental conditions at the APEI no. 3 also seem to be beyond the range of those found in exploration contract areas, which may explain why the community structure and species composition of benthic assemblages are so different. 

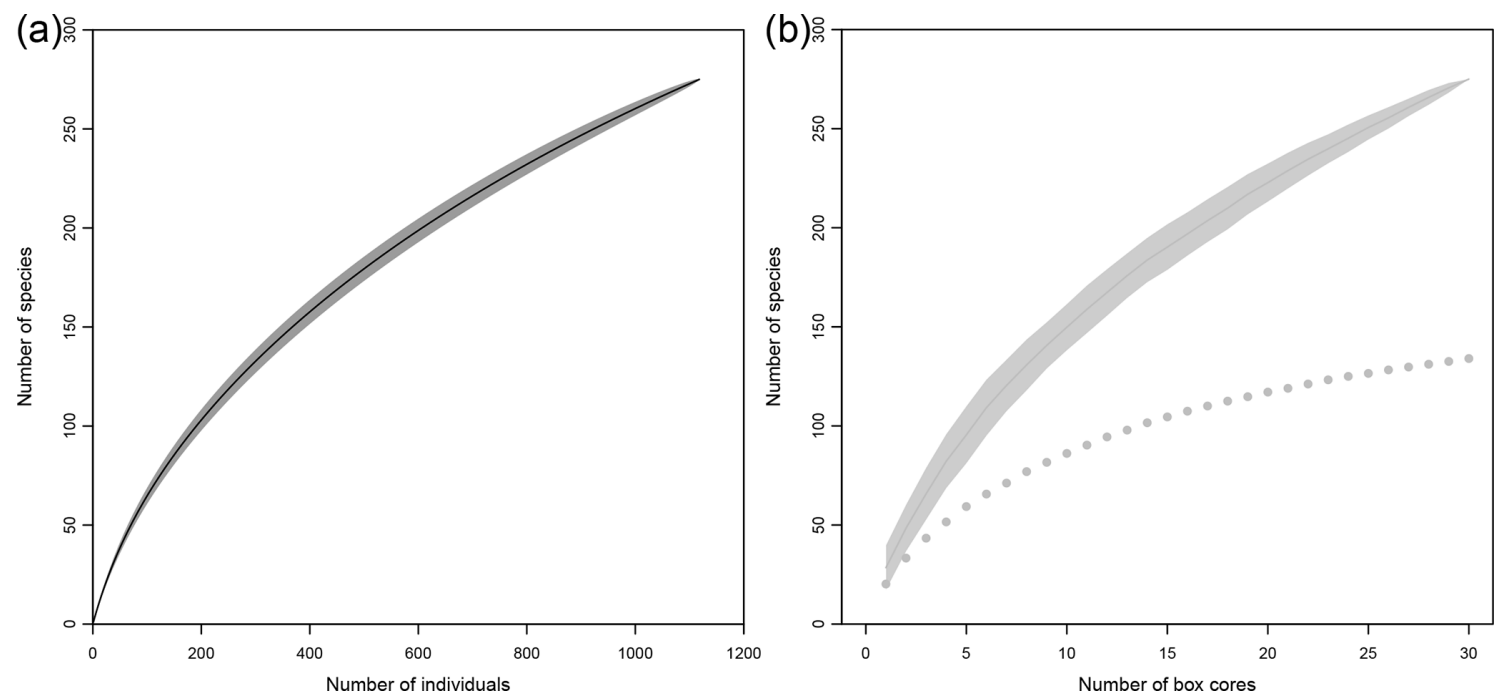

Figure 10. Rarefaction curves based on individuals (a) and samples (b) within the eastern CCFZ. The dotted curve shows the sample-based rarefaction curve of singletons.

\subsection{Species turnover and geographic ranges}

Species turnover was best illustrated by the distance decay of NNESS similarity, which showed two different patterns. Firstly, APEI no. 3 showed very low similarity with all other areas, irrespective of distance. Secondly, similarity decayed linearly with distance among the exploration contract areas located within the CCFZ. Beyond variation in food inputs, as discussed above, the large dissimilarity of polychaete assemblages in APEI no. 3 may suggest a major physiographic barrier between the north and south of the Clarion Fracture. The Clarion Fracture Zone is a long and narrow submarine mountain range characterized by a peak and trough exceeding $1800 \mathrm{~m}$ difference in elevation (Hall and Gurnis, 2005), which may be a barrier to dispersal for abyssal fauna. In the Atlantic, the Vema-TRANSIT expedition tested the influence of the Mid-Atlantic Ridge (MAR) and the Vema Fracture Zone (VFZ) on distribution and connectivity patterns of abyssal fauna with contrasting results (Riehl et al., 2018a). The MAR is not a barrier to dispersal for nematode species of the genus Acantholaimus (Lins et al., 2018), a pattern already found for 61 copepod species of the genus Mesocletodes (Menzel et al., 2011). However, the MAR is differently permeable to dispersal for three families of isopods, depending on their habits and swimming abilities (Bober et al., 2018). In particular, connectivity was very low for Macrostylidae species, a family of burrowing isopods with limited dispersal abilities (Riehl et al., 2018b). The species composition of the two polychaete families Spionidae and Polynoidae also differed on both sides of the VFZ, which may be due to limited dispersal and different habitat characteristics (Guggolz et al., 2018). This was, however, not the case for species of Laonice, which tended to show large ranges of up to $4000 \mathrm{~km}$ across the eastern and western At- lantic (Guggolz et al., 2019), or species of Aurospio and Prionospio, which could show pan-oceanic distribution (i.e., $\mathrm{Pa}$ cific and Atlantic oceans; Guggolz et al., 2020). Our observations about Aurospio sp. 249, which was the only species sampled in all five areas, confirm the potential to disperse across large geographic distances of some spionids (Guggolz et al., 2020). In the CCFZ, Bonifácio and Menot (2019) described 17 new species of polynoids based on morphology and DNA, of which 4 species are shared between APEI no. 3 and the exploration areas. In the abyssal Pacific, the CCFZ and the Peru Basin share 9 species of scavenging amphipods, which are highly motile and thus potentially cross the Clipperton and Galapagos fracture zones (Patel et al., 2018). However, species identification was based on morphology only, although cryptic species are common among scavenging amphipods, even in abyssal lineages (Brandt et al., 2012; Havermans et al., 2013). The influence of the fracture zones on the dispersal of the abyssal fauna remains to be better understood as the Clarion and Clipperton fractures may act as a barrier for species with low dispersal abilities, such as infaunal brooders. If so, the representativeness of seven out of the nine APEIs, which lie partly beyond the fractures, may be questionable.

Moreover, the slope of the linear decay of NNESS similarity within the CCFZ suggests an average range of 14 to $25 \mathrm{~km}$ per species. This average range masks large variance between a small pool of widespread species, known from two or more areas, and a large pool of rare species, only known from one study area and, in most cases, only known from a single individual. This high frequency of singletons may also significantly bias the estimation of species ranges (see below for a discussion on singletons). However, based on the best knowledge we have, our study suggests that, on average, the spatial range of polychaete species in the CCFZ is on the order of 
$20 \mathrm{~km}$. This figure can be compared with the scale of a mining operation (Volkmann et al., 2018; Volkmann and Lehnen, 2018): rounding the production rate to $1.5 \mathrm{Mt} \mathrm{yr}^{-1}$ and using a nodule density of $15 \mathrm{~kg} \mathrm{~m}^{-2}$, an area of a $100 \mathrm{~km}^{2}$ would be mined each year. In other words, every year nodule mining would affect an area that is equivalent to the average geographic range of polychaete species.

\subsection{The under-sampling bias: how many polychaete species live in the CCFZ?}

Considering that the economic feasibility of nodule mining requires, for any single operation, mining a minimum of ca. $100 \mathrm{~km}^{2}$ of abyssal seafloor per year for a couple of decades (Volkmann et al., 2018; Volkmann and Lehnen, 2018), there is no doubt that the benthic ecosystem will be subjected to adverse environmental impacts and that recovery, if any, will take centuries (Miljutin et al., 2011; Vanreusel et al., 2016; Gollner et al., 2017; Jones et al., 2017). The main issue that has to be addressed is how significant these adverse impacts will be: will they cause "serious harm" (Levin et al., 2016) and, in particular, what will be the magnitude of biodiversity loss (Van Dover et al., 2017)? To assess the significance of adverse impacts due to nodule mining, one of the key unknowns is whether the deep sea, including abyssal fauna, is hyper-diverse (Hessler and Jumars, 1974; Grassle and Maciolek, 1992; Paterson et al., 1998) or not (May, 1992; Rex et al., 2005).

Locally, alpha diversity of polychaete assemblages is high in the CCFZ (Paterson et al., 1998; Glover et al., 2002; Wilson, 2017), particularly for the equitability component of diversity, as exemplified by the slopes of individual-based rarefaction curves and a ratio of individuals to species of two to three at a local scale. Rarefaction curves level off at none of the sampling areas, highlighting that species richness has been systematically under-sampled, even at DOMES A, where 41 box-cores have been sampled (Wilson, 2017). At a regional scale, Glover et al. (2002) reported a total of 177 polychaete species in $2.94 \mathrm{~m}^{2}$ along a $3260 \mathrm{~km}$ latitudinal gradient of productivity in the NE Pacific and a total of 183 species in $21 \mathrm{~m}^{2}$ along a $2800 \mathrm{~km}$ longitudinal transect crossing the CCFZ. Janssen et al. (2015) found 233 MOTUs of polychaetes from epibenthic sledge samples of the BGR and Ifremer areas separated by $1400 \mathrm{~km}$. Along this same transect, using an integrative taxonomy approach, here we report a total of 275 species from 30 quantitative box cores, covering an area of $7.5 \mathrm{~m}^{2}$. The two latter studies, relying partly or totally on DNA bar-coding, yield higher numbers of species than the two former regional assessments based on morphology only. Our personal observations during the identification process effectively allowed the identification of cryptic species sometimes sympatrically distributed. This presence of cryptic species has been already observed by Janssen et al. (2015) and Bonifácio and Menot (2019), with the former suggesting that the specific environmental condi- tions have already selected for the best morphological characters, resulting in convergent speciation in other aspects as well, such as behavior or physiology. Integrative taxonomy thus not only provides more accurate estimates of species diversity but also facilitates comparisons across datasets. Over $90 \%$ of the species in the abyssal Pacific are new to science (Glover et al., 2002) and there are few attempts to try to name them (Paterson et al., 2016; Bonifácio and Menot, 2019), although DNA sequences can easily be matched. Therefore, 26 MOTUs are shared between Janssen et al. (2015) and our study. The overlap is low, but it should be noted that we had only $71 \mathrm{COI}$ sequences belonging to 45 MOTUs to compare with the $556 \mathrm{COI}$ sequences belonging to 233 MOTUs from Janssen et al. (2015). This highlights a shortcoming of COIbased bar-coding because success rates for $\mathrm{COI}$ sequencing are generally low. A combination of several genetic markers associated to formal morphological descriptions are thus essential to accurately assess species diversity. In addition, Janssen et al. (2015) used an epibenthic sledge and we used a box corer. These two devices sample different components of benthic communities. During the SO239 cruise, epibenthic sledge samples provided a collection of 278 specimens and 80 MOTUs of polynoids, a family of larger epifaunal polychaetes (Bonifácio et al., 2016; Bonifácio and Menot, 2019), but in our box core samples, we only found one polynoid.

Overall, the combination of high local diversity, unsaturated rarefaction curves, high levels of cryptic diversity and high rates of species turnover suggest that polychaete diversity in the CCFZ is large and vastly under-sampled. Within the eastern CCFZ, the linear decay of NNESS similarity suggests a species turnover of 0.04 to 0.07 species km $\mathrm{km}^{-1}$, and decomposition of the beta diversity shows that $90 \%$ of dissimilarity is due to spatial turnover. This rate of species change is 1 order of magnitude higher than the rate found by Wilson (2017) for polychaetes $\left(0.0056\right.$ species $\left.\mathrm{km}^{-1}\right)$ and even higher than the rate for isopods $\left(0.012\right.$ species $\left.\mathrm{km}^{-1}\right)$. These discrepancies may again reflect a high level of cryptic diversity. Wilson (2017) acknowledged that the rates of change he found may be underestimated, particularly for polychaetes, due to the fact that identifications were based on morphology only. The rate of species turnover that we report here for a $1440 \mathrm{~km}$ transect across the eastern CCFZ is, however, 20 times lower than the rates of 1 species km ${ }^{-1}$ reported by Grassle and Maciolek (1992) from a $180 \mathrm{~km}$ transect at $2100 \mathrm{~m}$ in the northwestern Atlantic. This difference is roughly consistent with Grassle and Maciolek (1992) hypothesis that in the deepest and most oligotrophic parts of the ocean, species richness may be lower by 1 order of magnitude. Still, an extrapolation of our rate of species turnover to the 6 million $\mathrm{km}^{2}$ of the CCFZ, as Grassle and Maciolek (1992) did for the whole deep sea, yields predictions of at least 240000 polychaete species, i.e., a number of species equivalent to the number of accepted marine species globally (WoRMS, 2019). 
This prediction is in sharp contrast with the outcome of nonparametric estimators of species richness, such as Chao or Jackknife, which provide a maximum estimate of 498 species. However, such estimators implicitly assume that the number of singletons decreases with increasing sample size (Melo, 2004), but the number of singletons steadily increased with sample size in this study. In such circumstances, the nonparametric species estimators underestimates species richness (Melo, 2004; Coddington et al., 2009). In an intensive survey of spiders in 1 ha of tropical forest, Coddington et al. (2009) found $29 \%$ of singletons and tested the null hypothesis of under-sampling against ecologically driven hypotheses to explain this "anomalously" high frequency of singletons. They concluded that under-sampling was the most parsimonious explanation for the high frequency of singletons and that it causes a systematic negative bias of species richness estimators. In the deep sea, an anomalously high rate of singletons (about one-third of the sampled species) is usually the rule of macrofaunal surveys (Gage, 2004), and the most parsimonious hypothesis that still needs to be tested is thus that the deep-sea macrofauna has been systematically under-sampled.

Although under-sampling causes an underestimation of species richness, it may also lead to an overestimation of the distance decay of similarity because singletons, considered endemic to an area in the analysis, may have much wider distributions. In conclusion, our level of certainty on the number of polychaete species inhabiting the CCFZ and potentially threatened by nodule mining ranges from 498 to 240000 species. The former estimate assumes that we have already sampled about half of the regional diversity and further suggests that most species have a large geographical range. The latter estimate assumes that we have sampled $0.1 \%$ of the polychaete species in the CCFZ and that these species have narrow geographical ranges about the size of the area that will presumably be mined in 1 year by a single mining operation.

\section{Conclusions}

Food inputs and nodule density influence the structure and composition of polychaete assemblages in the CCFZ. This is a confirmation of hypotheses underpinning the design of the APEIs. Increasingly oligotrophic conditions cause two shifts in the trophic structure and species composition of polychaete assemblages. The first shift suggests that within the eastern central subregion defined by Wedding et al. (2013) and sampled in the present study, the eastern contract areas (BGR, IOM and GSR) and the western contract (Ifremer) belong in fact to different subregions, and if so they should be represented by two different APEIs. The most significant shift in community structure and composition was, however, found between the APEI no. 3 and the nodule exploration areas. APEI no. 3 is found in oligotrophic condi- tions north of the Clarion Fracture Zone, whereas exploration areas experience mesotrophic conditions south of the Clarion Fracture Zone. The scantiness of food supply and a barrier to dispersal may thus compromise the representativeness of APEI no. 3 and question its ability to meet its purpose of preserving the biodiversity from any of the contract areas considered in this study. However, the sampling effort in both the contract areas and the APEI remains quite limited. Furthermore, there are vast gaps in knowledge regarding life cycle and population dynamics that would need to be better constrained to fully assess the risks and provide guidance in mining management. In order to ascertain that the APEIs collectively meet their goal of preserving the biodiversity of the CCFZ an ambitious research agenda is needed, the funding of which could rely on the willingness of contractors and sponsoring states but could also become a priority of the future Environmental Compensation Fund to be created by the regulations on exploitation of mineral resources in the Area (ISBA/25/C/WP.1, 2019). The Area is defined by the United Nations Convention on the Law of the Sea (UNCLOS, 1982) as the seabed and subsoil beyond the limits of national jurisdiction.

The efficiency of the regional environmental management plan for the CCFZ is crucial in face of the yet uncertain but potentially adverse impacts of nodule mining. Within the CCFZ per se, the diversity of polychaete assemblages is even higher than previously thought due to a high level of cryptic diversity. Species turnover is high with a minimum estimated rate of species change of 0.04 species $\mathrm{km}^{-1}$, suggesting an average geographical range of $25 \mathrm{~km}$ and a number of polychaete species in the CCFZ that may equal the number of all currently known marine species. If true, the risk of species extinction is very high because the environmental footprint of nodule mining would largely exceed the range of many species. On the contrary, nonparametric estimators of species richness suggest that total species richness across the five study areas does not exceed 498 species, which likely implies a species range much larger than $25 \mathrm{~km}$. Both methods of estimating species richness can, however, be severely biased by singletons. Singletons represent $49 \%$ of the 275 species of polychaetes that were sampled. The most parsimonious hypothesis to explain such a high rate of singletons is under-sampling. Under the auspice of the ISA, the synthesis of ongoing studies from independent science and contractors in the CCFZ will certainly contribute in filling some knowledge gaps on species richness and turn over but differences in objectives, strategies and methodologies among studies are also likely to put some limits on the usefulness of the exercise. The JPI Oceans pilot action "Ecological aspects of deep-sea mining" demonstrated how powerful such a joined and coordinated initiative can be. In the framework of a similarly ambitious and collective effort to inventory species richness in the CCFZ, a stratified random sampling at nested scales from regional down to seascapes, would provide the scales of species turnover, while intensive sampling of se- 
lected habitats up to the point where the number of singletons decreases with sample size would provide accurate estimates of species diversity. Both strategies should consider different taxonomic and functional groups of the abyssal fauna, which are likely to show different responses to nodule mining. Such an approach, based on standardized sampling methods and statistical sampling strategies, is needed to assess the potential risks and scales of biodiversity loss due to nodule mining in the CCFZ.

Data availability. DNA sequences are available in BOLD (https://doi.org/10.5883/DS-GKG001; Bonifácio, 2019) or GenBank databases. The abundance data analyzed in the present study together with BOLD IDs (sample ID and process ID) and GenBank accession numbers are available in the PANGAEA database (https://doi.org/10.1594/PANGAEA.902860; Bonifácio et al., 2019).

Author contributions. LM and PMA conceived the project and designed the sampling. LM and PB performed the sampling and processed the samples. PB identified (morphology and DNA) the polychaetes. LM and PB analyzed and interpreted the data. All authors prepared and contributed to the manuscript.

Competing interests. The authors declare that they have no conflict of interest.

Special issue statement. This article is part of the special issue "Assessing environmental impacts of deep-sea mining - revisiting decade-old benthic disturbances in Pacific nodule areas". It is not associated with a conference.

Acknowledgements. The research leading to these results has received funding from the Ifremer program Ressources Minérales Marines (REMIMA), the JPI Oceans pilot action "Ecological aspects of deep-sea mining" and the European Union Seventh Framework Program (FP7/2007-2013) under the MIDAS project, grant agreement no. 603418. We are grateful to the crew of the RV Sonne and to all of the people involved in the field sampling and sample processing during the SO239 cruise. We would like to thank Stefanie Kaiser, Sarah Schnurr, and Ana Hilário for their expertise in washing and sieving samples and Lenka Neal for live-sorting the worms. Additionally, we thank Baptiste François for sample sorting in the laboratory. We are also grateful to all of the people that were involved in that molecular analysis: Aliou Dia, Guillaume Lannuzel, Emmanuelle Omnes, Alana Jute, Mohamed Dosoky and Gavin Campbell. Special thanks to Thomas Dahlgren for looking after and sharing the data of some families of polychaetes and to Ann Vanreusel, Freija Hauquier, and Felix Janssen for providing the abiotic data of CCFZ. Finally, we would like to thank Tina Treude and the referees (Paul Dando and three anonymous referees) for their critical reviews and useful comments, which significantly improved the quality of the final paper.
Financial support. This research has been supported by the Seventh Framework Programme (MIDAS, grant no. 603418). The study also received funding from REMIMA and JPI Oceans.

Review statement. This paper was edited by Tina Treude and reviewed by Paul Dando and three anonymous referees.

\section{References}

Amon, D. J., Ziegler, A. F., Dahlgren, T. G., Glover, A. G., Goineau, A., Gooday, A. J., Wiklund, H., and Smith, C. R.: Insights into the abundance and diversity of abyssal megafauna in a polymetallic-nodule region in the eastern Clarion-Clipperton Zone, Sci. Rep.-UK, 6, 30492 , https://doi.org/10.1038/srep30492, 2016.

Baselga, A.: Partitioning the turnover and nestedness components of beta diversity, Global Ecol. Biogeogr., 19, 134-143, https://doi.org/10.1111/j.1466-8238.2009.00490.x, 2010.

Błażewicz, M., Jóźwiak, P., Menot, L., and Pabis, K.: High species richness and unique composition of the tanaidacean communities associated with five areas in the Pacific polymetallic nodule fields, Prog. Oceanogr., 176, 102141, https://doi.org/10.1016/j.pocean.2019.102141, 2019.

Bober, S., Brix, S., Riehl, T., Schwentner, M., and Brandt, A.: Does the Mid-Atlantic Ridge affect the distribution of abyssal benthic crustaceans across the Atlantic Ocean?, Deep-Sea Res. Pt. II, 148, 91-104, https://doi.org/10.1016/j.dsr2.2018.02.007, 2018.

Böggemann, M.: Polychaetes (Annelida) of the abyssal SE Atlantic, Org. Divers. Evol., 9, 251-428, 2009.

Bonifácio, P. and Menot, L.: New genera and species from the Equatorial Pacific provide phylogenetic insights into deep-sea Polynoidae (Annelida), Zool. J. Linn. Soc.-Lond., 185, 555-635, https://doi.org/10.1093/zoolinnean/zly063, 2019.

Bonifácio, P., Neal, L., and Menot, L.: Diversity of polynoids (Polynoidae: Polychaeta) from Pacific and Southern Oceans, 12th International Polychaete Conference, National Museum Wales, Cardiff, 2016.

Bonifácio, P., Neal, L., Omnes, E., Baptiste, F., Dahlgren, T. G., and Menot, L.: The polychaete fauna of the Clarion-Clipperton Fracture Zone from boxcore samples during SONNE cruise SO239, PANGAEA, https://doi.org/10.1594/PANGAEA.902860, 2019.

Bonifácio, P.: Polychaete sequences from Clarion-Clipperton Fracture Zone sampled with box-corer during SONNE cruise SO239, BOLD, https://doi.org/10.5883/DS-GKG001, 2019.

Borcard, D., Gillet, F., and Legendre, P. (Eds.): Numerical ecology with R, Springer-Verlag, New York, USA, 2011.

Boudreau, B. P. and Scott, M. R.: A model for the diffusioncontrolled growth of deep-sea manganese nodules, Am. J. Sci., 278, 903-929, https://doi.org/10.2475/ajs.278.7.903, 1978.

Brandt, A., Błażewicz-Paszkowycz, M., Bamber, R., MühlenhardtSiegel, U., Malyutina, M., Kaiser, S., De Broyer, C., and Havermans, C.: Are there widespread peracarid species in the deep sea (Crustacea: Malacostraca)?, Pol. Polar Res., 33, 139-162, 2012.

Brasier, M. J., Wiklund, H., Neal, L., Jeffreys, R., Linse, K., Ruhl, H., and Glover, A. G.: DNA barcoding uncovers cryptic diversity in $50 \%$ of deep-sea Antarctic polychaetes, R. Soc. Open Sci., 3, 160432, https://doi.org/10.1098/rsos.160432, 2016. 
Burnham, K. P. and Overton, W. S.: Robust estimation of population size when capture probabilities vary among animals, Ecology, 60, 927-936, https://doi.org/10.2307/1936861, 1979.

Carr, C. M., Hardy, S. M., Brown, T. M., Macdonald, T. A., and Hebert, P. D. N.: A tri-oceanic perspective: DNA barcoding reveals geographic structure and cryptic diversity in Canadian polychaetes, PLoS ONE, 6, e22232, https://doi.org/10.1371/journal.pone.0022232, 2011.

Chao, A.: Nonparametric estimation of the number of classes in a population, Scand. J. Stat., 11, 265-270, 1984.

Chen, H. and Boutros, P. C.: VennDiagram: a package for the generation of highly-customizable Venn and Euler diagrams in R, BMC Bioinformatics, 12, 3327-3327, https://doi.org/10.1186/1471-2105-12-35, 2011.

Chiu, C. H., Wang, Y. T., Walther, B. A., and Chao, A.: An improved nonparametric lower bound of species richness via a modified good-turing frequency formula, Biometrics, 70, 671-682, https://doi.org/10.1111/biom.12200, 2014.

Coddington, J. A., Agnarsson, I., Miller, J. A., Kuntner, M., and Hormiga, G.: Undersampling bias: the null hypothesis for singleton species in tropical arthropod surveys, J. Anim. Ecol., 78, 573-584, https://doi.org/10.1111/j.1365-2656.2009.01525.x, 2009.

Cohen, B. L., Gawthrop, A., and Cavalier-Smith, T.: Molecular phylogeny of brachiopods and phoronids based on nuclear-encoded small subunit ribosomal RNA gene sequences, Philos. T. R. Soc. B., 353, 2039-2061, https://doi.org/10.1098/rstb.1998.0351, 1998.

Conover, W. J. and Iman, R. L.: On multiple-comparisons procedures, Los Alamos Scientific Laboratory, New Mexico LA-7677MS, 1979.

De Smet, B., Pape, E., Riehl, T., Bonifácio, P., Colson, L., and Vanreusel, A.: The community structure of deep-sea macrofauna associated with polymetallic nodules in the eastern part of the Clarion-Clipperton Fracture Zone, Front. Mar. Sci., 103, 4, https://doi.org/10.3389/fmars.2017.00103, 2017.

Dray, S., Bauman, D., Blanchet, G., Borcard, D., Clappe, S., Guenard, G., Jombart, T., Larocque, G., Legendre, P., Madi, N., and Wagner, H. H.: adespatial: Multivariate Multiscale Spatial Analysis, R package version 0.3-7, available at: https:// CRAN.R-project.org/package=adespatial (last access: 12 February 2020), 2019.

Edgar, R. C.: MUSCLE: multiple sequence alignment with high accuracy and high throughput, Nucleic Acids Res., 32, 1792-1797, https://doi.org/10.1093/nar/gkh340, 2004.

Fauchald, K.: Benthic polychaetous annelids from deep water off western Mexico and adjacent areas in the eastern Pacific Ocean, Univ. of Southern California, Los Angeles, 1972.

Fauchald, K.: The polychaete worms. Definitions and keys to the orders, families and genera, Natural History Museum of Los Angeles County, Science Series 28, 188 pp., 1977.

Folmer, O., Black, M., Hoeh, W. R., Lutz, R. A., and Vrijenhoek, R. C.: DNA primers for amplification of mitochondrial cytochrome c oxidase subunit I from diverse metazoan invertebrates, Mol. Mar. Biol. Biotech., 3, 294-299, 1994.

Friedrichs, M., Graf, G., and Springer, B.: Skimming flow induced over a simulated polychaete tube lawn at low population densities, Mar. Ecol. Prog. Ser., 192, 219-228, 2000.
Gage, J. D.: Diversity in deep-sea benthic macrofauna: the importance of local ecology, the larger scale, history and the Antarctic, Deep-Sea Res. Pt. II, 51, 1689-1708, 2004.

Gage, J. D. and Tyler, P. A.: Deep-sea biology: a natural history of organisms at the deep-sea floor, Cambridge University Press, Cambridge, U.K., 504 pp., 1991.

Gallagher, E. D.: COMPAH documentation, University of Massachusetts, available at: http://citeseerx.ist.psu.edu/viewdoc/ download?doi=10.1.1.9.1334\&rep=rep1\&type=pdf (last access: 12 February 2020), Boston, 65, 1996.

Global Sea Mineral Resources NV: Small-scale testing of nodule collector components on the seafloor of the Clarion-Clipperton Fracture Zone and its environmental impact, Environmental Impact Statement, DEME, 2018.

Glover, A., Dahlgren, T., Taboada, S., Paterson, G., Wiklund, H., Waeschenbach, A., Cobley, A., Martínez, P., Kaiser, S., Schnurr, S., Khodami, S., Raschka, U., Kersken, D., Stuckas, H., Menot, L., Bonifácio, P., Vanreusel, A., Macheriotou, L., Cunha, M., Hilário, A., Rodrigues, C., Colaço, A., Ribeiro, P., Błażewicz, M., Gooday, A., Jones, D., Billett, D., Goineau, A., Amon, D., Smith, C., Patel, T., McQuaid, K., Spickermann, R., and Brager, S.: The London workshop on the biogeography and connectivity of the Clarion-Clipperton Zone, Res. Ideas Outcomes, 2, e10528, https://doi.org/10.3897/rio.2.e10528, 2016.

Glover, A. G. and Smith, C. R.: The deep-sea floor: current status and prospects of anthropogenic change by the year 2025, Environ. Conserv., 30, 219-241, 2003.

Glover, A. G., Smith, C. R., Paterson, G. L. J., Wilson, G. D. F., Hawkins, L., and Sheader, M.: Polychaete species diversity in the central Pacific abyss: local and regional patterns, and relationships with productivity, Mar. Ecol.-Prog. Ser., 240, 157-170, https://doi.org/10.3354/meps240157, 2002.

Gollner, S., Kaiser, S., Menzel, L., Jones, D. O. B., Brown, A., Mestre, N. C., van Oevelen, D., Menot, L., Colaço, A., Canals, M., Cuvelier, D., Durden, J. M., Gebruk, A., Egho, G. A., Haeckel, M., Marcon, Y., Mevenkamp, L., Morato, T., Pham, C. K., Purser, A., Sanchez-Vidal, A., Vanreusel, A., Vink, A., and Martínez Arbizu, P.: Resilience of benthic deep-sea fauna to mining activities, Mar. Environ. Res., 129, 76-101, https://doi.org/10.1016/j.marenvres.2017.04.010, 2017.

Gotelli, N. J. and Colwell, R. K.: Quantifying biodiversity: Procedures and pitfalls in the measurement and comparison of species richness, Ecol. Lett., 4, 379-391, 2001.

Graf, G. and Rosenberg, R.: Bioresuspension and biodeposition: a review, J. Marine Syst., 11, 269-278, https://doi.org/10.1016/S0924-7963(96)00126-1, 1997.

Grassle, J. F. and Maciolek, N. J.: Deep-sea species richness: regional and local diversity estimates from quantitative bottom samples, Am. Nat., 139, 313-341, 1992.

Greinert, J.: Swath sonar multibeam EM122 bathymetry during SONNE cruise SO239 with links to raw data files, PANGAEA, https://doi.org/10.1594/PANGAEA.859456, 2016.

Guggolz, T., Lins, L., Meißner, K., and Brandt, A.: Biodiversity and distribution of polynoid and spionid polychaetes (Annelida) in the Vema Fracture Zone, tropical North Atlantic, Deep-Sea Res. Pt. II, 148, 54-63, https://doi.org/10.1016/j.dsr2.2017.07.013, 2018.

Guggolz, T., Meißner, K., Schwentner, M., and Brandt, A.: Diversity and distribution of Laonice species (Annelida: Spionidae) in 
the tropical North Atlantic and Puerto Rico trench, Sci. Rep.-UK, 9, 9260, https://doi.org/10.1038/s41598-019-45807-7, 2019.

Guggolz, T., Meißner, K., Schwentner, M., Dahlgren, T. G., Wiklund, H., Bonifácio, P., and Brandt, A.: High diversity and panoceanic distribution of deep-sea polychaetes: Prionospio and $\mathrm{Au}$ rospio (Annelida: Spionidae) in the Atlantic and Pacific Ocean, Org. Divers. Evol., https://doi.org/10.1007/s13127-020-00430-7, 2020.

Hall, C. E. and Gurnis, M.: Strength of fracture zones from their bathymetric and gravitational evolution, J. Geophys. Res.-Sol. Ea., 110, B01402, https://doi.org/10.1029/2004JB003312, 2005.

Hannides, A. and Smith, C.: The Northeastern Pacific Abyssal Plain, in: Biogeochemistry of Marine Systems, edited by: Black, K. S. and Shimmield, G. B., Blackwell Publishing Ltd, 208-237, 2003.

Hauquier, F., Macheriotou, L., Bezerra, T. N., Egho, G., Martínez Arbizu, P., and Vanreusel, A.: Distribution of free-living marine nematodes in the Clarion-Clipperton Zone: implications for future deep-sea mining scenarios, Biogeosciences, 16, 3475-3489, https://doi.org/10.5194/bg-16-3475-2019, 2019.

Havermans, C., Sonet, G., d'Udekem d'Acoz, C., Nagy, Z. T., Martin, P., Brix, S., Riehl, T., Agrawal, S., and Held, C.: Genetic and morphological divergences in the cosmopolitan deep-sea amphipod Eurythenes gryllus reveal a diverse abyss and a bipolar species, PLoS ONE, 8, e74218, https://doi.org/10.1371/journal.pone.0074218, 2013.

Hebert, P. D., Ratnasingham, S., and deWaard, J. R.: Barcoding animal life: cytochrome c oxidase subunit 1 divergences among closely related species, Proc. R. Soc. Lond. B, 270, S96-S99, https://doi.org/10.1098/rsbl.2003.0025, 2003b.

Hebert, P. D. N., Cywinska, A., Ball, S. L., and deWaard, J. R.: Biological identifications through DNA barcodes, P. R. Soc. Lond. B, 270, 313-321, https://doi.org/10.1098/rspb.2002.2218, 2003a.

Hessler, R. R. and Jumars, P. A.: Abyssal community analysis from replicate box cores in the central North Pacific, Deep-Sea Res., 21, 185-209, 1974.

Hein, J. R. and Petersen, S.: The geology of Manganese nodules, in: Deep Sea Minerals: Manganese Nodules, a physical, biological, environmental, and technical review, 1B, edited by: Baker, E. and Beaudoin, Y., Secretariat of the Pacific Community (SPC), Noumea, New Caledonia, 7-18, 2013.

Hollander, M. and Wolfe, D. A.: Nonparametric statistical methods, John Wiley \& Sons, New York, 1973.

Holm, S.: A Simple Sequentially Rejective Multiple Test Procedure, Scand. J. Stat., 6, 65-70, 1979.

Hurlbert, S. H.: The nonconcept of species diversity: a critique and alternative parameters, Ecology, 52, 577-586, 1971.

Hutchings, P.: Biodiversity and functioning of polychaetes in benthic sediments, Biodivers. Conserv., 7, 1133-1145, https://doi.org/10.1023/a:1008871430178, 1998.

ISBA/25/C/WP.1: Draft regulations on exploitation of mineral resources in the Area. International Seabed Authority, Kingston, Jamaica, available at: https://ran-s3.s3.amazonaws.com/isa.org. jm/s3fs-public/files/documents/isba_25_c_wp1-e.pdf (last access: 12 February 2020), 2019.

Janssen, A., Kaiser, S., Meißner, K., Brenke, N., Menot, L., and Martínez Arbizu, P.: A reverse taxonomic approach to assess macrofaunal distribution patterns in abyssal $\mathrm{Pa}$ - cific polymetallic nodule fields, PLoS ONE, 10, e0117790, https://doi.org/10.1371/journal.pone.0117790, 2015.

Jones, D. O. B., Kaiser, S., Sweetman, A. K., Smith, C. R., Menot, L., Vink, A., Trueblood, D., Greinert, J., Billett, D. S. M., Arbizu, P. M., Radziejewska, T., Singh, R., Ingole, B., Stratmann, T., Simon-Lledó, E., Durden, J. M., and Clark, M. R.: Biological responses to disturbance from simulated deepsea polymetallic nodule mining, PLoS ONE, 12, e0171750, https://doi.org/10.1371/journal.pone.0171750, 2017.

Jumars, P. A., Dorgan, K. M., and Lindsay, S. M.: Diet of worms emended: an update of polychaete feeding guilds, Annu. Rev. Mar. Sci., 7, 497-520, https://doi.org/10.1146/annurev-marine010814-020007, 2015.

Katoh, K., Misawa, K., Kuma, K., and Miyata, T.: MAFFT: a novel method for rapid multiple sequence alignment based on fast Fourier transform, Nucleic. Acids. Res., 30, 3059-3066, 2002.

Kindt, R. and Coe, R.: Tree diversity analysis. A manual and software for common statistical methods for ecological and biodiversity studies, World Agroforestry Centre (ICRAF), Nairobi, Kenya, 2005.

Legendre, P. and Legendre, L.: Chapter 11 - Canonical analysis, in: Developments in Environmental Modelling, edited by: Legendre, P. and Legendre, L., Elsevier, 625-710, 2012.

Legendre, P.: Interpreting the replacement and richness difference components of beta diversity, Global Ecol. Biogeogr., 23, 13241334, https://doi.org/10.1111/geb.12207, 2014.

Levin, L. A., Mengerink, K., Gjerde, K. M., Rowden, A. A., Van Dover, C. L., Clark, M. R., Ramirez-Llodra, E., Currie, B., Smith, C. R., Sato, K. N., Gallo, N., Sweetman, A. K., Lily, H., Armstrong, C. W., and Brider, J.: Defining "serious harm" to the marine environment in the context of deep-seabed mining, Mar. Policy, 74, 245-259, https://doi.org/10.1016/j.marpol.2016.09.032, 2016.

Lins, L., da Silva, M. C., Neres, P., Esteves, A. M., and Vanreusel, A.: Testing deep-sea biodiversity paradigms on abyssal nematode genera and Acantholaimus species, Deep-Sea Res. Pt. II, 148, 208-222, https://doi.org/10.1016/j.dsr2.2016.12.005, 2018.

Lodge, M., Johnson, D., Le Gurun, G., Wengler, M., Weaver, P., and Gunn, V.: Seabed mining: International Seabed Authority environmental management plan for the ClarionClipperton Zone. A partnership approach, Mar. Policy, 49, 6672, https://doi.org/10.1016/j.marpol.2014.04.006, 2014.

Magalhães, W. F. and Bailey-Brock, J. H.: Particle selection and feeding behaviour in two cirratulid polychaetes, J. Mar. Biol. Assoc. UK, 97, 1069-1074, https://doi.org/10.1017/s0025315417000522, 2017.

Martínez Arbizu, P. and Haeckel, M.: RV SONNE Fahrtbericht/Cruise Report SO239: EcoResponse Assessing the Ecology, Connectivity and Resilience of Polymetallic Nodule Field Systems, Balboa (Panama) - Manzanillo (Mexico) 11 March30 April 2015, GEOMAR Report, N. Ser. 025, GEOMAR Helmholtz-Zentrum für Ozeanforschung, Kiel, Germany, 2015.

May, R. M.: Bottom up for the oceans, Nature, 357, 278-279, 1992.

McClain, C. R. and Schlacher, T. A.: On some hypotheses of diversity of animal life at great depths on the sea floor, Mar. Ecol., 36, 849-872, https://doi.org/10.1111/maec.12288, 2015.

Medlin, L., Elwood, H. J., Stickel, S., and Sogin, M. L.: The characterization of enzymatically amplified eukary- 
otic 16S-like rRNA-coding regions, Gene, 71, 491-499, https://doi.org/10.1016/0378-1119(88)90066-2, 1988.

Melo, A. S.: A critique of the use of jackknife and related nonparametric techniques to estimate species richness, Community Ecol., 5, 149-157, 2004.

Menot, L.: ness: Hypergeometric standardization and probabilistic measures of similarity for community ecology. $\mathrm{R}$ package version 0.1.0, Zenodo, https://doi.org/10.5281/zenodo.3254750, 2019.

Menzel, L., George, K. H., and Arbizu, P. M.: Submarine ridges do not prevent large-scale dispersal of abyssal fauna: A case study of Mesocletodes (Crustacea, Copepoda, Harpacticoida), Deep-Sea Res. Pt. I, 58, 839-864, https://doi.org/10.1016/j.dsr.2011.05.008, 2011.

Miljutin, D. M., Miljutina, M. A., Arbizu, P. M., and Galéron, J.: Deep-sea nematode assemblage has not recovered 26 years after experimental mining of polymetallic nodules (ClarionClipperton Fracture Zone, Tropical Eastern Pacific), Deep-Sea Res. Pt. I, 58, 885-897, 2011.

Miljutina, M., Miljutin, D., Mahatma, R., and Galéron, J.: Deepsea nematode assemblages of the Clarion-Clipperton Nodule Province (Tropical North-Eastern Pacific), Mar. Biodivers., 40, $1-15,2010$.

Moore, J. C. and de Ruiter, P. C.: Invertebrates in detrital food webs along gradients of productivity, in: 2000, edited by: Colman, D. C. and Hendrix, P. F., CABI Publishing, 161-184, 2000.

Morgan, C. L.: Resource estimates of the Clarion-Clipperton manganese nodule deposits, in: Handbook of marine mineral deposits, edited by: Cronan, D. S., CRC Press, Boca Raton, 145170,2000

Murray, J. and Renard, A. F.: Report on the Scientific Results of the Voyage of HMS Challenger During the Years 1873-76: Deep-Sea Deposits, Hodges, Figgis, \& Company, Dublin, 1891.

Nygren, A. and Sundberg, P.: Phylogeny and evolution of reproductive modes in Autolytinae (Syllidae, Annelida), Mol. Phylogenet. Evol., 29, 235-249, https://doi.org/10.1016/S10557903(03)00095-2, 2003.

Oebius, H. U., Becker, H. J., Rolinski, S., and Jankowski, J. A.: Parametrization and evaluation of marine environmental impacts produced by deep-sea manganese nodule mining, DeepSea Res. Pt. II, 48, 3453-3467, https://doi.org/10.1016/S09670645(01)00052-2, 2001.

O'Hara, R. B.: Species richness estimators: how many species can dance on the head of a pin?, J. Anim. Ecol., 74, 375-386, https://doi.org/10.1111/j.1365-2656.2005.00940.x, 2005.

Oksanen, J., Blanchet, F. G., Kindt, R., Legendre, P., Minchin, P. R., O’Hara, R. B., Simpson, G. L., Solymos, P., Stevens, M. H. H., and Wagner, H.: vegan: Community Ecology Package, R package version 2.2-1, available at: http://CRAN.R-project.org/ package=vegan (last access: 12 February 2020), 2015.

Palumbi, S. R.: Nucleic acid II: the polymerase chain reaction, in: Molecular Systematics, edited by: Hillis, D. M., Moritz, G., and Mable, B., Sinauer Associates, Sunderland, MA, 1996.

Patel, T., Robert, H., D'Udekem D'Acoz, C., Martens, K., De Mesel, I., Degraer, S., and Schön, I.: Biogeography and community structure of abyssal scavenging Amphipoda (Crustacea) in the Pacific Ocean, Biogeosciences Discuss., https://doi.org/10.5194/bg-2018-347, in review, 2018.
Paterson, G. L. J., Wilson, G. D. F., Cosson, N., and Lamont, P. A.: Hessler and Jumars (1974) revisited: abyssal polychaete assemblages from the Atlantic and Pacific, Deep-Sea Res. Pt. II, 45, 225-251, 1998.

Paterson, G. L. J., Neal, L., Altamira, I., Soto, E. H., Smith, C. R., Galeron, J., Menot, L., Billett, D. S. M., Cunha, M., and Glover, A. G.: New Prionospio and Aurospio Species from the Deep Sea (Annelida: Polychaeta), Zootaxa, 4092, 1-32, 2016.

Post, D. M.: The long and short of food-chain length, Trends Ecol. Evol., 17, 269-277, https://doi.org/10.1016/S01695347(02)02455-2, 2002.

Radziejewska, T.: Responses of deep-sea meiobenthic communities to sediment disturbance simulating effects of polymetallic nodule mining, Int. Rev. Hydrobiol., 87, 457-477, 2002.

Ramirez-Llodra, E., Brandt, A., Danovaro, R., De Mol, B., Escobar, E., German, C. R., Levin, L. A., Martinez Arbizu, P., Menot, L., Buhl-Mortensen, P., Narayanaswamy, B. E., Smith, C. R., Tittensor, D. P., Tyler, P. A., Vanreusel, A., and Vecchione, M.: Deep, diverse and definitely different: unique attributes of the world's largest ecosystem, Biogeosciences, 7, 2851-2899, https://doi.org/10.5194/bg-7-2851-2010, 2010.

Ratnasingham, S. and Hebert, P. D. N.: bold: The Barcode of Life Data System (http://www.barcodinglife.org), Mol. Ecol. Notes, 7, 355-364, https://doi.org/10.1111/j.1471-8286.2007.01678.x, 2007.

R Core Team: R: A language and environment for statistical computing, R Foundation for Statistical Computing, Vienna, Austria, 2018.

Rex, M. A., McClain, C. R., Johnson, N. A., Etter, R. J., Allen, J. A., Bouchet, P., and Waren, A.: A source-sink hypothesis for abyssal biodiversity, Am. Nat., 165, 163-178, 2005.

Riehl, T., Kaiser, S., and Brandt, A.: Vema-TRANSIT - An interdisciplinary study on the bathymetry of the VemaFracture Zone and Puerto Rico Trench as well as abyssal Atlantic biodiversity, Deep-Sea Res. Pt. II, 148, 1-6, https://doi.org/10.1016/j.dsr2.2018.01.007, 2018a.

Riehl, T., Lins, L., and Brandt, A.: The effects of depth, distance, and the Mid-Atlantic Ridge on genetic differentiation of abyssal and hadal isopods (Macrostylidae), Deep-Sea Res. Pt. II, 148 , 74-90, https://doi.org/10.1016/j.dsr2.2017.10.005, 2018b.

Rowe, G. T., Sibuet, M., Deming, J. M., Khripounoff, A., Tietjen, J., Macko, S. A., and Theroux, R.: "Total" sediment biomass and preliminary estimates of organic carbon residence time in deepsea benthos, Mar. Ecol.-Prog. Ser., 79, 99-114, 1991.

RStudio Team: RStudio: Integrated Development for R. RStudio, Inc, Boston, MA, 2015.

Simon-Lledó, E., Bett, B. J., Huvenne, V. A. I., Schoening, T., Benoist, N. M. A., and Jones, D. O. B.: Ecology of a polymetallic nodule occurrence gradient: Implications for deep-sea mining, Limnol. Oceanogr., 64, 1883-1894, https://doi.org/10.1002/lno.11157, 2019.

Sjölin, E., Erséus, C., and Källersjö, M.: Phylogeny of Tubificidae (Annelida, Clitellata) based on mitochondrial and nuclear sequence data, Mol. Phylogenet. Evol., 35, 431-441, https://doi.org/10.1016/j.ympev.2004.12.018, 2005.

Smith, C. R. and Demopoulos, A. W. J.: The Deep Pacific ocean floor, in: Ecosystems of the Deep Oceans, edited by: Tyler, P. A., Ecosystem of the World 28, Elsevier Science, Amsterdam, 179218, 2003. 
Smith, C. R., Berelson, W., Demaster, D. J., Dobbs, F. C., Hammond, D., Hoover, D. J., Pope, R. H., and Stephens, M.: Latitudinal variations in benthic processes in the abyssal equatorial Pacific: control by biogenic particle flux, Deep-Sea Res. Pt. II, 44, 2295-2317, https://doi.org/10.1016/S0967-0645(97)000222, 1997.

Smith, C. R., De Leo, F. C., Bernardino, A. F., Sweetman, A. K., and Arbizu, P. M.: Abyssal food limitation, ecosystem structure and climate change, Trends Ecol. Evol., 23, 518-528, 2008a.

Smith, C. R., Paterson, G. L. D., Lambshead, P. J. D., Glover, A., Rogers, A. D., Gooday, A. J., Kitazato, H., Sibuet, M., Galéron, J., and Menot, L.: Biodiversity, species ranges, and gene flow in the abyssal Pacific nodule province: predicting and managing the impacts of deep seabed mining, International Seabed Authority, Kingston, Jamaica, 38, 2008b.

Smith, E. P. and van Belle, G.: Nonparametric estimation of species richness, Biometrics, 40, 119-129, https://doi.org/10.2307/2530750, 1984.

Sokolova, M. N.: Trophic Structure of Abyssal Macrobenthos, in: Adv. Mar. Biol., edited by: Blaxter, J. H. S., Southward, A. J., Gebruk, A. V., Southward, E. C., and Tyler, P. A., Academic Press, 427-525, 1997.

Sternberg, R. W.: Field measurements of the hydrodynamic roughness of the deep-sea boundary, Deep-Sea Res. Oceanogr. Abstr., 17, 413-420, https://doi.org/10.1016/0011-7471(70)900562, 1970.

Suess, E.: Particle organic carbon flux in the oceans-surface productivity and oxygen utilization, Nature, 228, 260-263, 1980.

Thiel, H., Schriever, G., Bussau, C. and Borowski, C.: Manganese nodule crevice fauna, Deep-Sea Res. Pt. 1, 40, 419-423, https://doi.org/10.1016/0967-0637(93)90012-R, 1993.

Trueblood, D. D., Gallagher, E. D., and Gould, D. M.: Three stages of seasonal succession on the Savin Hill Cove mudflat, Boston Harbor, Limnol. Oceanogr., 39, 1440-1454, 1994.

UNCLOS: United Nations Convention on the Law of the Sea, Montego Bay, Jamaica, In force 16 November 1994, available at: https://www.un.org/depts/los/convention_agreements/ convention_overview_convention.htm (last access: 12 February 2020), 1982.

Van Dover, C. L., Ardron, J. A., Escobar, E., Gianni, M., Gjerde, K. M., Jaeckel, A., Jones, D. O. B., Levin, L. A., Niner, H. J., Pendleton, L., Smith, C. R., Thiele, T., Turner, P. J., Watling, L., and Weaver, P. P. E.: Biodiversity loss from deep-sea mining, Nat. Geosci., 10, 464-465, https://doi.org/10.1038/ngeo2983, 2017.
Vanreusel, A., Hilario, A., Ribeiro, P. A., Menot, L., and Arbizu, P. M.: Threatened by mining, polymetallic nodules are required to preserve abyssal epifauna, Sci. Rep.-UK, 6, 26808, https://doi.org/10.1038/srep26808, 2016.

Vavrek, M.: fossil: palaeoecological and palaeogeographical analysis tools. Palaeontol, Electronica, 14, 1T, 2011.

Volkmann, S. E. and Lehnen, F.: Production key figures for planning the mining of manganese nodules, Mar. Georesour. Geotec., 36, 360-375, https://doi.org/10.1080/1064119X.2017.1319448, 2018.

Volkmann, S. E., Kuhn, T., and Lehnen, F.: A comprehensive approach for a techno-economic assessment of nodule mining in the deep sea, Miner. Econ., 31, 319-336, https://doi.org/10.1007/s13563-018-0143-1, 2018.

Volz, J. B., Mogollón, J. M., Geibert, W., Arbizu, P. M., Koschinsky, A., and Kasten, S.: Natural spatial variability of depositional conditions, biogeochemical processes and element fluxes in sediments of the eastern Clarion-Clipperton Zone, Pacific Ocean, Deep-Sea Res. Pt. I, 140, 159-172, https://doi.org/10.1016/j.dsr.2018.08.006, 2018.

Wedding, L. M., Friedlander, A. M., Kittinger, J. N., Watling, L., Gaines, S. D., Bennett, M., Hardy, S. M., and Smith, C. R.: From principles to practice: a spatial approach to systematic conservation planning in the deep sea, P. R. Soc. Lond. B, 280, 20131684 , https://doi.org/10.1098/rspb.2013.1684, 2013.

Westberry, T., Behrenfeld, M. J., Siegel, D. A., and Boss, E.: Carbon-based primary productivity modeling with vertically resolved photoacclimation, Global Biogeochem. Cy., 22, GB2024, https://doi.org/10.1029/2007gb003078, 2008.

Wilson, G. D. F.: Macrofauna abundance, species diversity and turnover at three sites in the Clipperton-Clarion Fracture Zone, Mar. Biodivers., 47, 323-347, https://doi.org/10.1007/s12526016-0609-8, 2017.

WoRMS: World Register of Marine Species, https://doi.org/10.14284/170, 2019.

Yu, O. H., Lee, H.-G., Kim, D., Wi, J. H., Kim, K. H., and Yoo, C. M.: Characterization of Deep-sea Macrofauna in the Korean Exploration Claim Area in the Clarion-Clipperton Fracture Zone, Northeastern Pacific Ocean, Ocean Sci. J., 53, 301-314, https://doi.org/10.1007/s12601-018-0029-8, 2018. 